\title{
Diagnostic Immunohistochemistry in Cutaneous Neoplasia: An Update
}

\author{
Leigh A. Compton George F. Murphy Christine G. Lian \\ Program in Dermatopathology, Department of Pathology, Brigham and Women's Hospital, \\ Harvard Medical School, Boston, Mass., USA
}

\author{
Key Words \\ Immunohistochemistry · Skin cancer · Cutaneous neoplasia · Biomarkers
}

\begin{abstract}
Immunohistochemistry (IHC) is an important adjunct in the diagnosis of neoplastic skin diseases. In addition to the many established IHC markers currently in use, new markers continue to emerge, although their general acceptance and routine application requires robust validation. Here, we summarize the most well-established and commonly used biomarkers along with an array of newer ones reported in the past several decades that either demonstrate or hold high clinical promise in the field of cutaneous pathology. We also highlight recent applications of novel IHC markers in melanoma diagnosis including genetic mutation status markers [e.g. BRAF ( $v$-raf murine sarcoma viral oncogene homolog B) and NRAS (neuroblastoma RAS viral oncogene homolog)] and an epigenetic alteration marker (e.g. 5-hydroxymethylcytosine). We specifically focus on the role of IHC in the differential diagnosis of cutaneous lesions that fall under the following categories: melanoma, epidermal tumors with an intraepidermal epitheliomatous pattern, spindle cell lesions of the dermis, small round blue cell tumors of the dermis, and cutaneous adnexal tumors. While IHC is a valuable tool in diagnostic dermatopathology, marker selection and interpretation must be highly informed by clinical context and the histologic differential diagnosis. With rapid progress in our understanding of the genetic and epigenetic mechanisms of tumorigenesis, new IHC markers will continue to emerge in the field of diagnostic dermatopathology.

(c) 2015 S. Karger AG, Basel
\end{abstract}

\section{Introduction}

While the routine practice of dermatopathology relies predominantly on histologic findings and clinical context, immunohistochemistry (IHC) will remain an important adjunct tool for the diagnosis of difficult cases, tumor staging and identification of genetic variants of therapeutic significance. The utility of IHC is broad across cutaneous neoplasms but becomes 
Table 1. IHC staining patterns in normal skin

\begin{tabular}{|c|c|c|c|}
\hline Antigen & Antibodies & Internal control & Figure \\
\hline Pan-cytokeratin & AE1/3 (AE1-acidic CK; AE3-basic CK), Pan-K & suprabasal keratinocytes & $1 \mathrm{a}, \mathrm{b}, \mathrm{f}$ \\
\hline HMWCK & $34 \beta \mathrm{E} 12$ (CK1, 5, 10, 14, 15), CK5/6 & $\begin{array}{l}\text { suprabasal keratinocytes and adnexal } \\
\text { epithelia }\end{array}$ & $1 c, d$ \\
\hline LMWCK & CAM5.2, CK7 & $\begin{array}{l}\text { secretory portion of eccrine and } \\
\text { apocrine glands }\end{array}$ & $1 \mathrm{e}$ \\
\hline Muscle markers & SMA, desmin & pilar smooth muscle & $2 a-d$ \\
\hline Eccrine and apocrine glands & CEA, EMA & sweat glands & $2 \mathrm{e}, \mathrm{f}$ \\
\hline Endothelial cell markers & CD31, CD34, vWF, ERG-1 & endothelial cells in vessels & $3 a-d$ \\
\hline Melanocytic markers & S100, MART-1, MITF, HMB-45, tyrosinase & epidermal basal layer melanocytes & 4 \\
\hline Langerin & CD1a, CD4 & epidermal Langerhans cells & \\
\hline Axon & NPF, S100 & nerve bundle & \\
\hline
\end{tabular}

LMWCK = Low-molecular-weight cytokeratin; NPF = neuropeptide F; vWF = von Willebrand factor; Pan-K = pan-keratin.

particularly powerful when 'extracutaneous' lesions, such as metastatic carcinoma, soft tissue neoplasms and hematologic malignancies enter the differential. Overreliance upon or uninformed utilization of biomarkers, however, can be treacherous due to the diagnostic pitfalls they can create. Here, we summarize some of the most commonly used and newly emerged biomarkers for the diagnosis of cutaneous neoplasms.

\section{Staining Patterns of the Common IHC Markers in Normal Skin}

Skin is rich in normal internal positive controls for the majority of antigens used as markers of neoplastic lesions, including keratinocytes, melanocytes, Langerhans cells and Merkel cells, as well as vessels, muscle and nerve bundles (table 1; fig. 1-3) [1]. For example, the cells of secretory coils of eccrine sweat glands are positive for low-molecular-weight cytokeratin, including CK7, cell adhesion molecule 5.2 (CAM5.2), carcinoembryonic antigen (CEA) and epithelial membrane antigen (EMA), while acrosyringeal cells of the intraepidermal portion of sweat glands are positive for high-molecular-weight cytokeratins (HMWCK). Careful attention to positive and negative internal controls is a critical first step in the interpretation of IHC staining.

\section{IHC Markers for Melanoma Diagnosis}

Melanoma is the most lethal type of skin malignancy, causing approximately $75 \%$ of skin cancer-related deaths worldwide [2]. Optimal therapy and patient prognosis for melanoma critically depend on early detection and accurate diagnosis. Given the tremendous histologic diversity of melanoma, diagnosis can be challenging [3]. Melanocytic lesions are now the second highest source of litigation in surgical pathology, following only lesions of the breast $[4,5]$. Utilization of a panel of melanocytic IHC markers can be an extremely valuable adjunct to hematoxylin and eosin (H\&E) morphology for the diagnosis of melanoma, although what 
Fig. 1. Keratin expression in normal skin. a, c, e Staining patterns of pan-keratin (Pan-K), HMWCK (CK5) and low-molecular-weight cytokeratin (LMWCK; CAM5.2) in normal skin. Pan-K (a) and HMWCK CK5 (c) highlight epidermal and follicular epithelium as well as dermal eccrine myoepithelium; e LMWCK CAM5.2 stains eccrine myoepithelium but not the epidermis or follicular epithelium. b, d, $\mathbf{f}$ Staining patterns of Pan-K, CK5 and AE1/AE3 in epidermis. Basal layers of the epidermis and hair follicle strongly express Pan-K (b) and HMWCK CK5 (d), while more superficial cell layers show decreased expression with cell maturation. $\mathbf{f}$ By contrast, more superficial/mature layers of the epidermis and follicle show strong expression of AE1/AE3, while the basal layers show little expression.

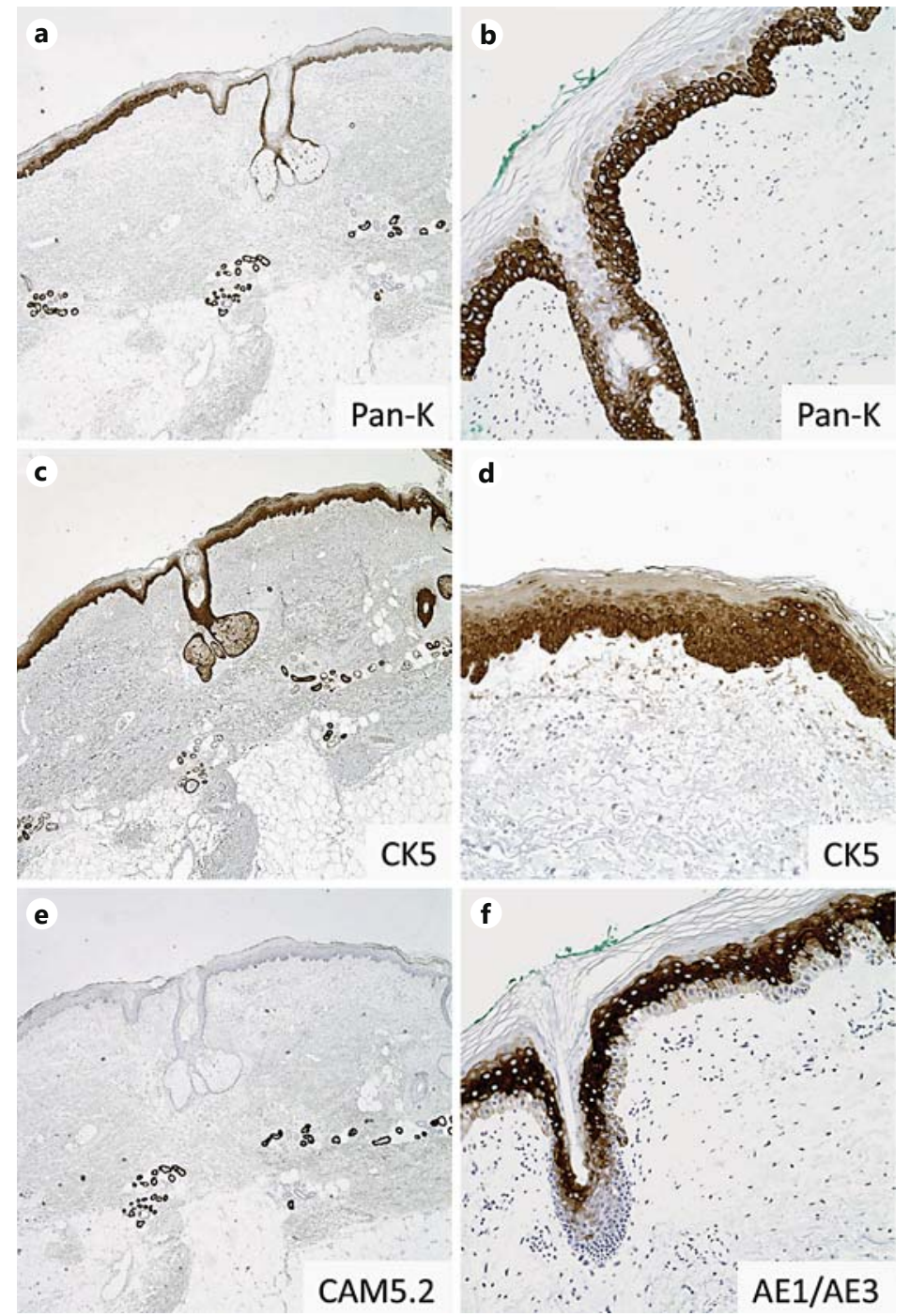

appears to be routine use of such panels by some laboratories for a majority of melanocytic lesions is inappropriate [6,7]. Accordingly, stringent and informed selection of cases that require IHC as a diagnostic adjunct is of utmost importance.

Among all IHC markers, $\mathrm{S} 100$ is among the most sensitive for melanocytic lesions, although it lacks specificity. Melanoma antigen recognized by T cells (MART-1), micropthalmia-associated transcription factor (MITF) and/or human melanoma black-45 (HMB-45) are frequently used because they provide increased specificity and reasonable sensitivity for differentiating most conventional melanomas from nonmelanocytic histologic mimics. HMB-45 has additional utility in differentiating benign melanocytic lesions from malignant melanoma as benign lesions (e.g. dermal nevi) tend to show decreased expression with lesion depth/maturation, while melanoma often shows more consistent staining in the deeper component. However, numerous exceptions exist, particularly in the setting of certain nevic variants of melanoma. Thus, interpretation of HMB-45 staining is not always straightforward, and expression (or lack thereof) should never be a single or dominant criterion in the establishment of a benign versus a malignant lesion. IHC is also useful in gauging confluent (contiguous/continuous) junctional growth of intraepidermal melanocytic proliferations or extent of pagetoid spread to help rule 
Fig. 2. Pilosebaceous unit IHC markers in normal skin. a, b SMA is strongly expressed in pilar muscle (arrows), eccrine myoepithelium (arrowheads) and vascular smooth muscle (not shown) in normal skin. c, d Pilar muscle also strongly expresses desmin (arrows). e Adnexal ducts are highlighted by CEA. f EMA immunostain highlights the luminal lining of adnexal ducts and sebaceous glands.
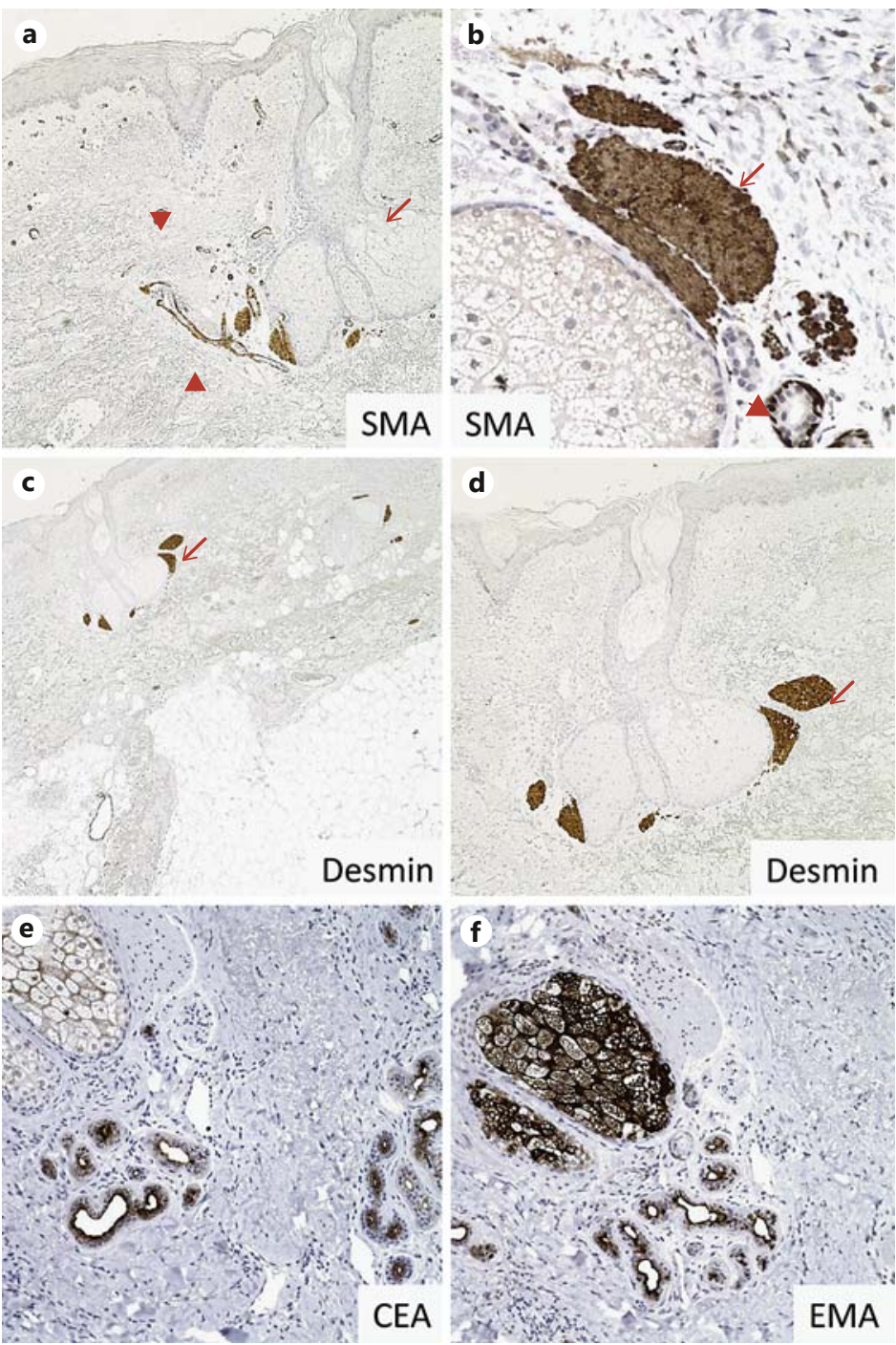

CEA d
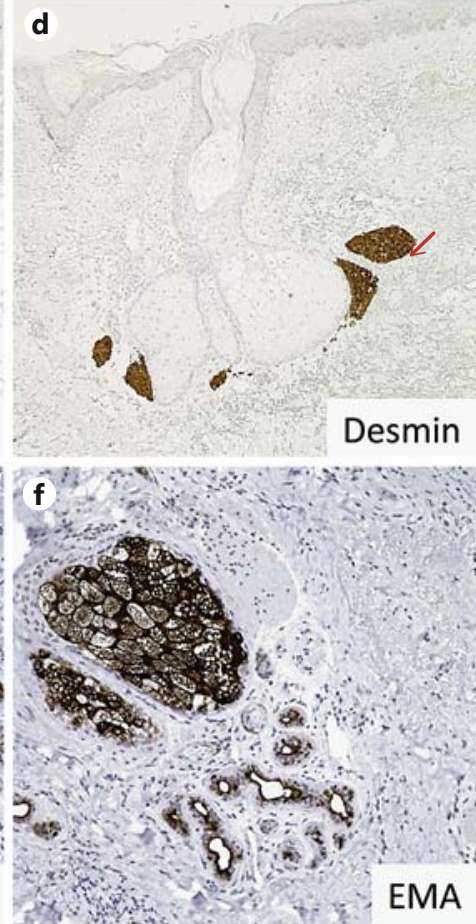

in or out a diagnosis of melanoma in situ or an in situ melanoma component of a worrisome compound melanocytic lesion. Although MART-1 is widely used for this purpose, the degree of confluent growth may be overestimated due to positive staining of melanocyte dendritic processes that wrap around keratinocytes and/or as a consequence of false-positive 'overstaining' [7-10] (fig. 4a-d). For these reasons, some prefer staining with the nuclear marker MITF when evaluating possible confluent lentiginous growth of the intraepidermal components of melanocytic lesions [7-10]. IHC for keratin may also be useful, as it provides the negative image of an intraepidermal melanocytic proliferation [11]. Of note, it is important to be aware of a few reports of melanomas with heterologous differentiation that express keratin, vimentin, EMA or smooth muscle actin (SMA), and such cases may create difficult diagnostic pitfalls, particularly in the setting of metastatic malignancy [3, 12-14], further emphasizing the value of assessing a complementary panel of well-selected biomarkers when faced with challenging neoplasms of potential melanocytic differentiation.

Surrogate IHC Markers for Mitoses in Melanoma - Phosphorylated Histone H3 and Ki-67

In the 7th edition of the American Joint Committee on Cancer (AJCC) Staging Manual, mitoses within the dermal/invasive component were added to the tumor staging criteria for 
Fig. 3. Lymphovascular IHC markers in normal skin. a CD31 highlights endothelial cells of dermal vessels. b D2-40 highlights the lining of dermal lymphatic channels but does not stain vascular endothelium (asterisk). c CD34 highlights dermal vascular endothelium and dermal mesenchymal cells. d ERG-1 is a nuclear stain of vascular endothelium.
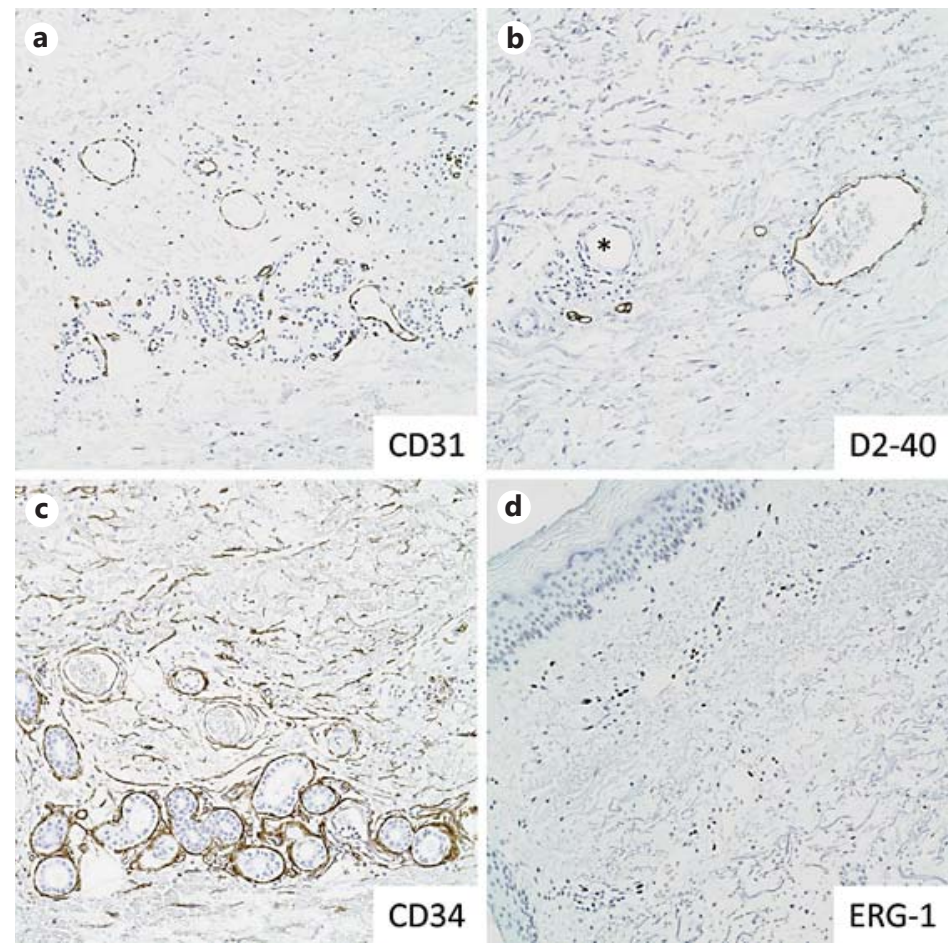

primary cutaneous melanoma [15] as their presence is believed to have significant prognostic value. While mitotic counts are a routine part of the practice of pathology, accurate evaluation in skin biopsies and excisions may be challenging due to the small sample size and as a result of histologic mimics, such as apoptotic tumor cells or mitoses in surrounding inflammatory or stromal cells. Studies have demonstrated a potential role for immunohistochemical markers of proliferation in the staging of primary cutaneous melanoma. Phosphorylated histone $\mathrm{H} 3$ (pHH3) is a general marker of cell proliferation whose utility in melanocytic lesions remains under active investigation. Histone H3 is phosphorylated during late G2/ early $\mathrm{M}$ phases of the cell cycle coincident with chromatin condensation and is dephosphorylated between late anaphase and telephase, making pHH3 a useful proxy of cell division. Data suggest that pHH3 staining successfully highlights mitoses in cutaneous melanomas and reduces interobserver variability $[16,17]$. Co-staining for $\mathrm{pHH} 3$ with one or more markers of melanoma, such as MART-1, may further improve accurate enumeration of mitoses restricted to cells of melanocytic lineage and reduce time spent on analysis $[16,18]$. In these studies, a mitosis was counted if the cell lacked a nuclear membrane and the chromatin was condensed and positive for $\mathrm{pHH}$. Multiple studies have identified the $\mathrm{pHH} 3$ index to be a powerful independent prognostic factor that rivals, and in some cases exceeds, the predictive value of histologic mitotic counts $[16,19,20]$. Double staining for a melanoma marker and limiting analysis to a mitotic 'hot spot', instead of the entire slide or specimen, has the greatest prognostic value [20]. Currently, the pHH3 index has not been introduced into standardized practice guidelines, such as the AJCC, and has not achieved widespread use in routine dermatopathology. For now, pHH3/melanoma marker co-stains serve to increase confidence in staging difficult cases of cutaneous melanomas, particularly when H\&E stains are equivocal.

Antigen KI-67 (Ki-67) is a nuclear protein expressed as two isoforms during the G1, S, G2 and $\mathrm{M}$ stages of cell division, making it a more sensitive (inclusive) marker of proliferation when compared with histologic mitotic counts or pHH3 staining approaches. Similar to pHH3, 
Fig. 4. Melanocytic markers. Melanoma in situ (a) highlighted by immunostains of $\mathrm{S} 100$ (b), MART1 (c) and MITF (d). e, f Ki-67 immunostain in a melanoma with a brisk tumor infiltrating lymphocytic response, highlighting the difficulty in interpreting lineage of Ki-67-positive cells. $\mathbf{g}$, h Double Ki-67 and MART-1 immunostains of melanoma, highlighting cell proliferation specifically in melanocytic lineages.
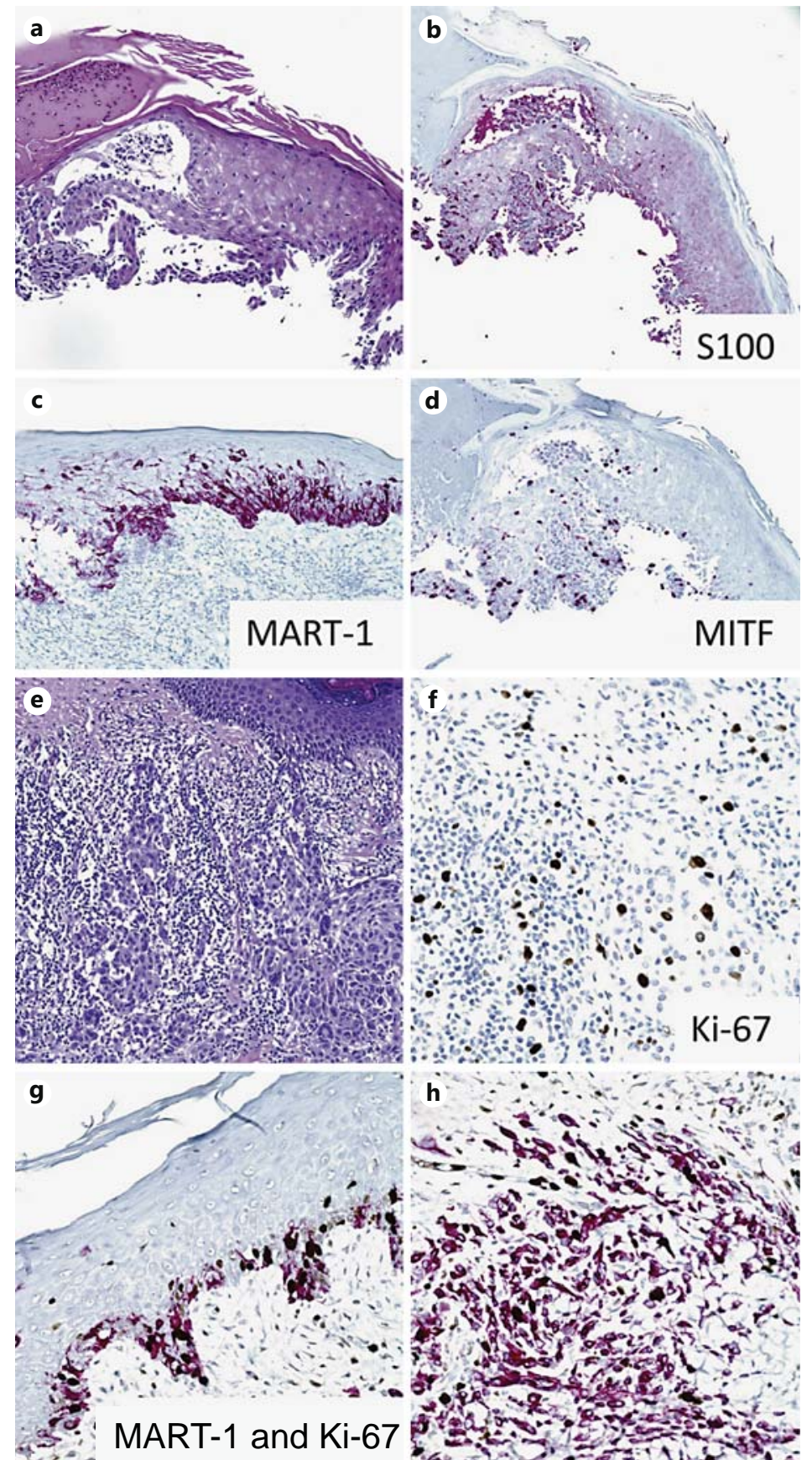

the Ki-67 index of cutaneous melanomas is a powerful, statistically significant, independent prognostic factor [20, 21]. Going forward, standardized Ki-67 indices would need to be established for melanoma by consensus prior to widespread use in staging. In melanomas with a brisk tumor-infiltrating lymphocyte response, single labeling with Ki-67 may lead to overestimation of the proliferative index due to the high density of mitotically active inflammatory cells (fig. 4e, f). In such cases, a Ki-67 and MART-1 double staining is recommended to clarify the histogenesis of proliferating cells (fig. $4 \mathrm{~g}$, h). Additionally, a recent report indicates that the mixed variant of desmoplastic melanoma (e.g. lesions also containing sarcomatoid or epithelioid regions) has a higher proliferative index based on Ki-67 IHC compared with the 
pure variant $[22,23]$. Studies with larger numbers of cases and a broader spectrum of melanocytic lesions to include nevi (especially traumatized and irritated lesions), Spitzoid lesions and borderline melanocytic lesions are needed to firmly establish the diagnostic and prognostic value of Ki-67 staining in melanocytic neoplasms.

\section{SRY (Sex-Determining Region Y)-Box 10}

SRY (sex-determining region Y)-box 10 (SOX10), a member of the Sry HMG box (Sox) family of transcription factors, is essential for maintenance of neural crest progenitor cells and their subsequent differentiation down melanocytic and glial lineages during embryogenesis [24]. Multiple studies have demonstrated that SOX10 is a highly sensitive immunohistochemical marker of both benign and malignant melanocytic lesions, making it a useful cell lineage indicator in the appropriate clinical context. Nearly $100 \%$ of primary melanomas display strong nuclear staining for SOX10 [25-27]. While SOX10 shows similarly high sensitivity for metastatic melanoma, staining intensity and the percentage of positive nuclei may be lower compared with benign melanocytic lesions and primary melanomas [25]. As with most IHC biomarkers, SOX10 should not be used in isolation for the diagnosis of metastatic lesions, particularly in the setting of unknown primary tumors, given that a subset of breast and salivary gland carcinomas stain positively for SOX10 [28-30], and expression has yet to be defined in many carcinomas. One area, however, where SOX10 may have particular utility is in differentiating desmoplastic melanoma from a variety of histologic mimics including fibrohistiocytic lesions, mesenchymal neoplasms, 'spindled' carcinomas and cellular excisional scars. Desmoplastic melanoma often does not stain for proteins considered to have higher specificity for conventional melanoma, such as MART-1, MITF and HMB-45. S100 is a highly sensitive marker of desmoplastic melanoma, but is also expressed by a number of mimics, including excisional scars, limiting its diagnostic utility. SOX10, however, is strongly expressed in $100 \%$ of desmoplastic melanomas [25-27,31], but not in the majority of spindle cell mimics, including a variety of sarcomas, spindle cell squamous cell carcinoma (SCC), fibrohistiocytic lesions such as Rosai Dorfman, atypical fibroxanthoma (AFX), dermatofibroma, Langerhans cell histiocytosis (LCH), juvenile xanthogranuloma, cellular neurothekeoma, reticulohistiocytoma, and the most frequently encountered (and perhaps treacherous mimic) cellular scar $[25,26,31]$. Thus, SOX10 may be particularly useful in evaluating residual desmoplastic melanoma and assessing its proximity to margins in reexcision specimens. Of note, SOX10 is expressed in 100\% of clear cell sarcomas, $100 \%$ of neurofibromas and schwannomas and approximately $50 \%$ of malignant peripheral nerve sheath tumors (MPNST). As such, SOX10 should not be utilized to differentiate these entities from melanoma. However, in most instances, histologic features alone should suffice (the diagnosis of spindled cell dermal tumors is further discussed in a subsequent section). In addition to positivity for SOX10, clear cell sarcomas frequently show at least partial positivity for other melanocytic markers including S100, MITF, Melan A and HMB-45 [32, 33]. Unlike melanoma, however, approximately $75 \%$ of clear cell sarcomas harbor a $\mathrm{t}(12 ; 22)(\mathrm{q} 13 ; \mathrm{q} 12)$ that creates an EWS-ATF1 fusion protein known to activate the MITF promoter in a SOX10-dependent manner [34]. PCR-based methods and fluorescent in situ hybridization may be used to detect this chromosomal translocation [35], which has never been described to occur in melanoma.

\section{Genetic and Epigenetic IHC Markers with Potential Clinical Implications}

The recent rapid progress in our understanding of the genetic and epigenetic mechanisms of melanomagenesis has heralded a new set of biomarkers of potential clinical importance. Recent studies demonstrate that IHC is a practical and easy method to detect the genetic mutational status of BRAF V600E (fig. 5a, b) and NRAS Q16R (fig. 5c) in melanoma. Genetic mutations in v-raf murine sarcoma viral oncogene homolog B (BRAF) and neuroblastoma 
Fig. 5. IHC markers for genetic mutations and epigenetic alteration in melanoma. a, b Cytoplasmic positivity of BRAFV 600E immunostains highlights the melanoma cells with BRAF V600E mutation. c Intratumoral heterogeneity shown by NRAS (Q61R) immunostains correlates with the different NRAS Q16R mutational status confirmed by high-resolution melting analysis and sequencing of NRAS exon 3. Reprinted from Modern Pathology with permission from Nature Publishing Group. IHC for epigenetic DNA hydroxymethylation mark (5-hmC) shows significant loss of 5-hmC positivity in metastatic melanoma (e) compared with strong staining intensity in nevus (d).
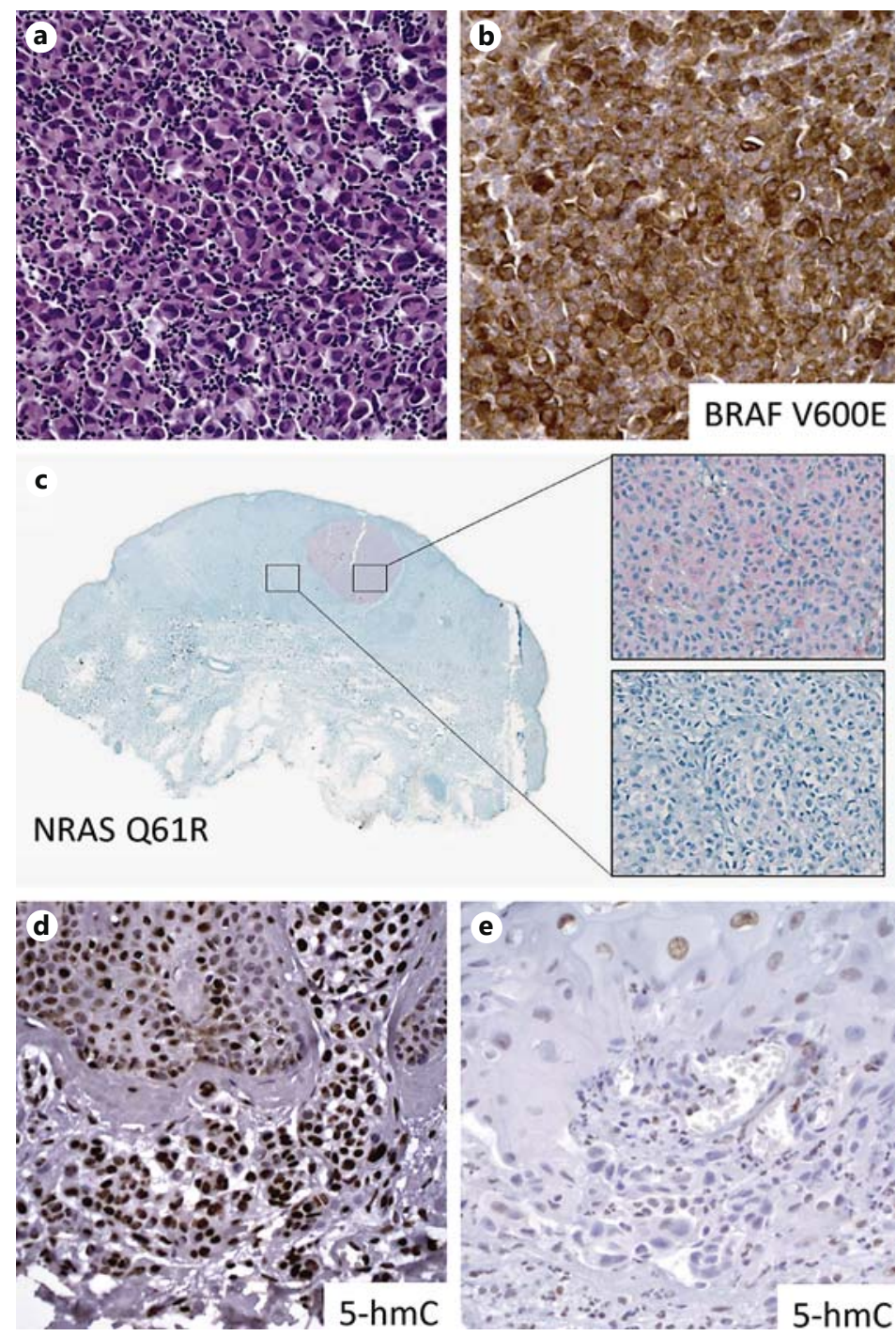

RAS viral oncogene homolog (NRAS) are present in approximately 50 and $20 \%$ of melanomas, respectively [36, 37], and result in constitutive activation of MAPK pathways. The RAS-RAFMAPK pathway has, in fact, proven to be a key therapeutic target for the treatment of metastatic melanoma, as multiple inhibitors either have achieved FDA approval, or are under investigation in clinical trials (e.g. BRAF inhibitor vemurafenib, MEK inhibitors). As such, accurate and rapid tests to assay mutational status are essential. Currently, molecular genetic testing is the preferred assay to determine BRAF inhibitor eligibility due to its superior sensitivity. Recent studies have shown that IHC for BRAF V600E and NRAS Q16R has excellent specificity that is highly concordant with molecular testing (e.g. PCR, pyrosequencing or nextgeneration sequencing) [38-41]. Other point mutations of BRAF (V600K, V600Q, and V600R) or NRAS (Q61K, Q61L, Q61H) melanomas do not stain positively with BRAF VE1 and NRAS Q61R antibodies $[39,41]$, respectively. In addition, studies indicate that germline mutation of BRAC1-associated protein (BAP-1) is associated with multiple cutaneous Spitzoid melanocytic neoplasms, as well as frequent somatic mutations in uveal melanoma [42-44]. The loss of BAP-1 in BAP-1 mutant melanocytic lesions can be detected by IHC [42-44]. 
In addition to genomic mutations, recent data demonstrate that epigenetic alterations play important roles in melanoma pathogenesis. Our group reported that detection by IHC of the loss of the DNA hydroxymethylation mark, 5-hydroxymethylcytosine (5-hmC), is a putative biomarker with diagnostic and prognostic value in melanoma [45] (fig. 5d, e). Additional studies by our group and others have demonstrated clinical application of immunohistochemical evaluation of 5-hmC, particularly with respect to differentiating micrometastases in sentinel lymph nodes from dermal nevic nests, and in the evaluation of melanocytic dysplasia [45-49].

Other markers under active investigation for their utility in the diagnosis and staging of melanoma include RUNX3 [50, 51], MAP-2 [52], nucleolin protein [53], KIT and p16 [54]. We also have noted that melanomas express the embryonic stem cell transcription factor SOX2 [55]. While not lineage specific, its expression appears to correlate with a more invasive phenotype [56], and IHC may be practically useful, when used in combination with detection of the intermediate filament protein nestin in verifying nodal melanoma metastases [57].

\section{IHC Biomarkers for Prediction of Response to Melanoma Therapy}

Given the recent progress of melanoma immunotherapy with regard to the blockade of immune checkpoints [e.g. CTLA-4 Ig and programmed cell death (PD-1) and programmed cell death ligand 1 (PD-L1)], there is urgent need to develop biomarkers to predict treatment responses. A recent study showed that PD-L1 IHC highlighted metastatic melanoma cells with membrane positivity in 30/81 (37\%) of patients [58]. By multivariate analysis, Breslow thickness and PD-L1 membrane positivity were independent risk factors for melanomaspecific death [58]. However, interpretation of PD-1 and PD-L1 IHC stains requires caution given the expression of these epitopes on immune cells within the tumor microenvironment $[59,60]$. Nonetheless, the ability to profile expression of potentially targetable immune checkpoints in melanoma tissue as a means of stratifying patients who may benefit most from specific therapies holds significant promise for personalized melanoma therapies. IHC to assess induction of metastasis infiltrating lymphocytes may also be used as one potential measure of immunotherapeutic treatment efficacy, as has recently been shown in a patient cohort treated with bevacizumab (VEGF inhibitor) and ipilimumab (CTLA-4 blocker) [61]. The importance of biomarker validation prior to clinical application has recently been emphasized in reference to a prominent report, based largely on in vitro data, implicating detection of hepatocyte growth factor in melanoma stroma as a means of predicting response to RAF inhibitors [62]. Detailed examination of this possibility using a large cohort and meticulously controlled reagents, however, failed to support this claim [63], further emphasizing the necessity for rigorous validation testing of any new biomarker that may potentially be employed in the care of patients.

\section{Epidermal Tumors with Intraepidermal Epitheliomatous Pattern}

The differential diagnosis of intraepithelial lesions can be difficult given their frequent overlap in architectural and cytomorphologic patterns. Moreover, diagnostic pitfalls can be compounded by superficial and fragmented biopsies that only show part of the lesion. SCC, extramammary Paget's disease (EMPD), malignant melanoma, Merkel cell carcinoma (MCC), LCH and adnexal carcinoma (sebaceous, eccrine, and apocrine) can all exhibit pagetoid and nested patterns of intraepidermal growth in the presence or absence of an invasive/dermal component. And while most cases of these entities can be diagnosed by routine histology, IHC can be of considerable assistance in the diagnosis of problematic lesions, thus avoiding diagnostic pitfalls that may impact on patient care [64]. 
Fig. 6. IHC markers for epidermal tumors with intraepitheliomatous pattern. a, b p63 expression in normal skin and squamous cell carcinoma. The epidermis, hair follicle and basal layers of the sebaceous unit express p63, with the strongest expression present towards the basal-most layers. p63 highlights myoepithelial cells of the eccrine units/ducts (arrowheads). Squamous cell carcinoma intensely expresses p63. c, d IHC for HMWCK $34 \beta E 12$ highlights basal cell carcinoma. e, f HE sections of EMPD show Paget tumor cells in epidermis and extend into dermis. LMWCK immunostains CAM5.2 (g) and CK7 (h) highlight tumor cells in EMPD.
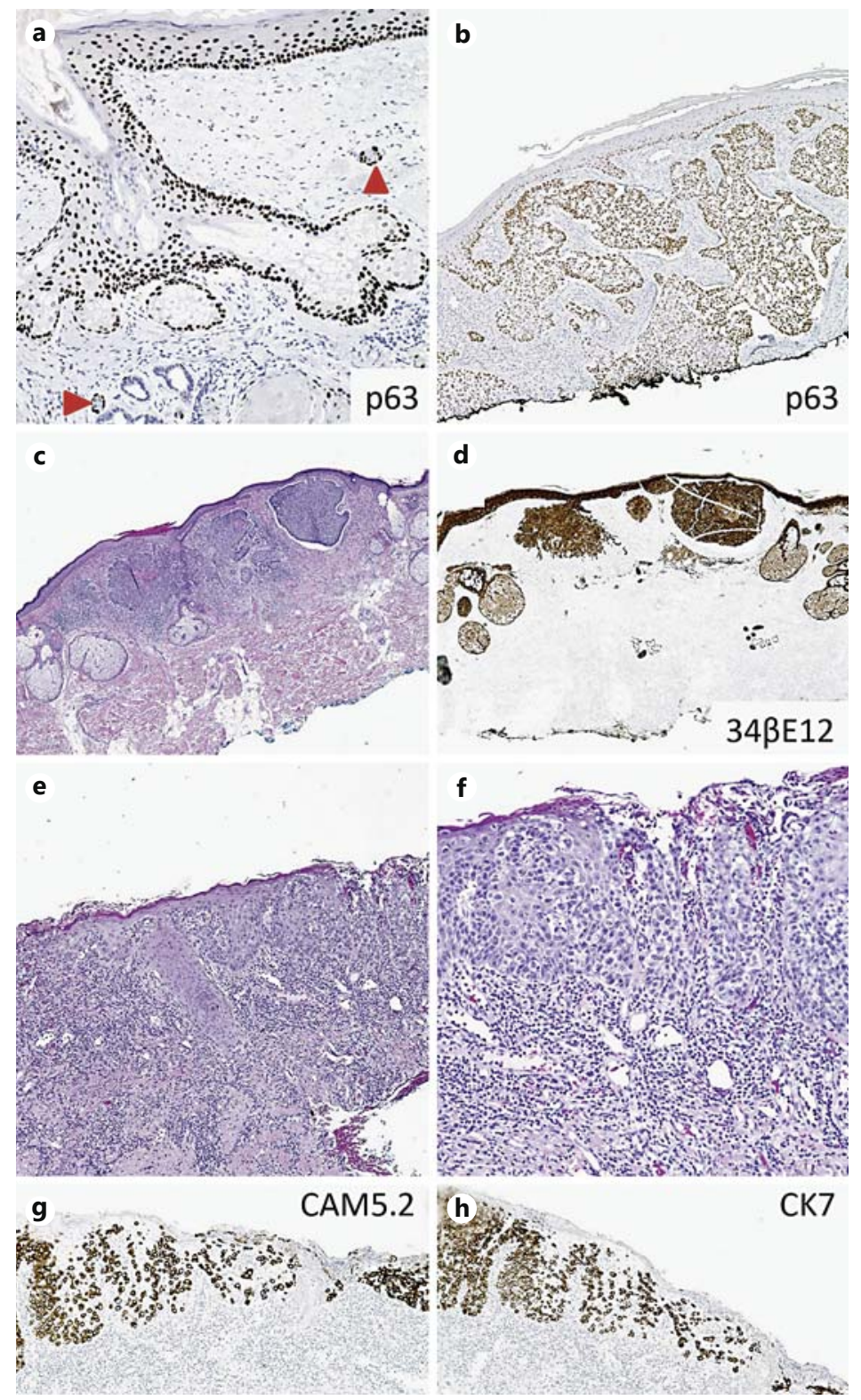

In situ SCC and melanoma, as well as EMPD are among the most frequently encountered entities demonstrating pagetoid growth patterns [65-68], and both occasionally will closely mimic pagetoid radial growth in melanoma. Historically, immunohistochemical positivity for CK7 and Cam5.2 has been utilized to favor a diagnosis of EMPD over SCC, and it also assists in excluding pagetoid radial growth phase melanoma. However, while invasive SCC does not frequently express these markers, recent data suggest pagetoid/'Bowenoid' SSCIS is frequently positive for CK7 and CAM5.2 [66, 69, 70]. p63, encoded on chromosome $3 q 27-28$, is a p53 homolog required for epidermal development and stem cell maintenance $[71,72]$. Due to its nuclear pattern of positivity, many regard this stain as easier to interpret, compared with cytokeratin reactivity. p63 is strongly expressed in normal basal and suprabasal epidermal layers and basal cells of sebaceous and sweat glands [73], and is not 
Table 2. IHC panels for epidermal tumors with intraepitheliomatous patterns

\begin{tabular}{|c|c|c|c|c|c|c|c|}
\hline & MMIS & SCCIS & MCC & Seb CIS & LCH & EMPD & BCC \\
\hline Screening & S100 & p63, EMA & CK20 & $\begin{array}{l}\text { EMA, AR, } \\
\text { adipophilin }\end{array}$ & $\begin{array}{l}\text { CD1a, } \\
\text { langerin }\end{array}$ & LMWCK & Ber-EP4 \\
\hline$\overline{\mathrm{EMA}}$ & $\begin{array}{l}5 \% \\
{[161]}\end{array}$ & $\begin{array}{l}79-96 \% \\
{[66,83,170,171]}\end{array}$ & $\begin{array}{l}100 \% \\
{[81]}\end{array}$ & $\begin{array}{l}91-100 \% \\
{[83,85,171]}\end{array}$ & $\begin{array}{l}0 \% \\
{[93]}\end{array}$ & $\begin{array}{l}100 \% \\
{[172]}\end{array}$ & $\begin{array}{l}0-6 \% \\
{[83,170,171]}\end{array}$ \\
\hline Androgen R & $\begin{array}{l}0 \% \\
{[173]}\end{array}$ & $\begin{array}{l}0-10 \% \\
{[83,84]}\end{array}$ & - & $\begin{array}{l}83-100 \% \\
{[83-85]}\end{array}$ & - & $\begin{array}{l}52-80 \% \\
{[86,87]}\end{array}$ & $\begin{array}{l}33-60 \% \\
{[83,85]}\end{array}$ \\
\hline Ber-EP4 & $\begin{array}{l}0 \% \\
{[78]}\end{array}$ & $\begin{array}{l}0-2 \% \\
{[66,83,170]}\end{array}$ & $\begin{array}{l}75 \% \\
{[79]} \\
\end{array}$ & $\begin{array}{l}6 \% \\
{[83]}\end{array}$ & - & $\begin{array}{l}100 \% \\
{[66,78]}\end{array}$ & $\begin{array}{l}80-100 \% \\
{[83,170,174]}\end{array}$ \\
\hline$\overline{\mathrm{CEA}}$ & - & $\begin{array}{l}20-30 \% \\
{[83,170]}\end{array}$ & $\begin{array}{l}0 \% \\
{[175]}\end{array}$ & $\begin{array}{l}42 \% \\
{[83]}\end{array}$ & - & $\begin{array}{l}100 \% \\
{[172]}\end{array}$ & $\begin{array}{l}0-20 \% \\
{[83,170,176]}\end{array}$ \\
\hline Adipophilin & - & $\begin{array}{l}0-10 \% \\
{[83,88]}\end{array}$ & $\begin{array}{l}0 \% \\
{[89]}\end{array}$ & $\begin{array}{l}92-97 \% \\
{[83,88,89]}\end{array}$ & - & - & $\begin{array}{l}0 \% \\
{[83,88]}\end{array}$ \\
\hline$\overline{C D 1 a}$ & $\begin{array}{l}0 \% \\
{[91,177]}\end{array}$ & $\begin{array}{l}\text { Negative } \\
{[178,179]}\end{array}$ & - & - & $\begin{array}{l}94-100 \% \\
{[180]}\end{array}$ & - & - \\
\hline Langerin & - & - & - & - & $\begin{array}{l}99-100 \% \\
{[92,180]}\end{array}$ & - & - \\
\hline CK7 & $\begin{array}{l}0 \% \\
{[66]}\end{array}$ & $\begin{array}{l}0-40 \% \\
{[174]}\end{array}$ & $\begin{array}{l}50 \% \\
{[79]}\end{array}$ & $\begin{array}{l}75 \% \\
{[83]}\end{array}$ & - & $\begin{array}{l}100 \% \\
{[66,181]}\end{array}$ & $\begin{array}{l}0-70 \% \\
{[174,176,182]}\end{array}$ \\
\hline$\overline{\mathrm{CK} 20}$ & $\begin{array}{l}0 \% \\
{[82]}\end{array}$ & $\begin{array}{l}0 \% \\
{[183]}\end{array}$ & $\begin{array}{l}83-100 \% \\
{[80-82,170]}\end{array}$ & $\begin{array}{l}0 \% \\
{[83]}\end{array}$ & - & $\begin{array}{l}0 \% \\
{[181]}\end{array}$ & $\begin{array}{l}0 \% \\
{[176,182]}\end{array}$ \\
\hline Cam5.2 & $\begin{array}{l}0-10 \% \\
{[66,161]}\end{array}$ & $\begin{array}{l}0-10 \% \\
{[66,171,174]}\end{array}$ & $\begin{array}{l}100 \% \\
{[79,184]}\end{array}$ & $\begin{array}{l}73 \% \\
{[171]}\end{array}$ & - & $\begin{array}{l}100 \% \\
{[66,69]}\end{array}$ & $\begin{array}{l}20-95 \% \\
{[170,171,174,176]}\end{array}$ \\
\hline p63 & $\begin{array}{l}0 \% \\
{[75]}\end{array}$ & $\begin{array}{l}87-100 \% \\
{[73,74]}\end{array}$ & $\begin{array}{l}33 \% \\
{[185]}\end{array}$ & $\begin{array}{l}100 \% \\
{[186,187]}\end{array}$ & - & $\begin{array}{l}0-17 \% \\
{[76,77]}\end{array}$ & $\begin{array}{l}100 \% \\
{[73]}\end{array}$ \\
\hline$\overline{\mathrm{S} 100 \mathrm{~A}}$ & $\begin{array}{l}100 \% \\
{[82]}\end{array}$ & $\begin{array}{l}0 \% \\
{[188]}\end{array}$ & $\begin{array}{l}0-17 \% \\
{[82,175]}\end{array}$ & N/A & $\begin{array}{l}93-99 \% \\
{[93,180]}\end{array}$ & $\begin{array}{l}0 \% \\
{[189-191]}\end{array}$ & $\begin{array}{l}0 \% \\
{[188]}\end{array}$ \\
\hline MART-1 & $\begin{array}{l}94 \% \\
{[188]}\end{array}$ & $\begin{array}{l}0 \% \\
{[188]}\end{array}$ & - & - & - & - & $\begin{array}{l}0 \% \\
{[188]}\end{array}$ \\
\hline HMB 45 & $\begin{array}{l}100 \% \\
{[78,82]}\end{array}$ & $\begin{array}{l}0 \% \\
{[188]}\end{array}$ & $\begin{array}{l}0 \% \\
{[82]}\end{array}$ & - & - & $\begin{array}{l}0 \% \\
{[78]}\end{array}$ & $\begin{array}{l}0 \% \\
{[188]}\end{array}$ \\
\hline
\end{tabular}

MMIS = Malignant melanoma in situ. Numbers in square brackets indicate references.

expressed in terminally differentiated cells (fig. 6a). Thus, the majority of SCC and basal cell carcinoma (BCC) express p63 immunostains (fig. 6b-d; tables 2, 3), including intraepidermal epitheliomatous variants, while staining is generally negative for EMPD [73-77]. On the other hand, Ber-EP4 is a highly sensitive marker of EMPD and BCC that is not expressed by pagetoid/Bowenoid SCC or melanoma [66, 78] (fig. 6c, d). Therefore, a panel of Ber-EP4, p63, and a specific melanoma marker such as MART-1 would be effective in differentiating these entities (table 2; fig. 6).

Epidermotropic/in situ MCC is a rare entity that frequently expresses Ber-EP4 [79], making this marker a poor choice to differentiate it from EMPD, although cytomorphologic features of these two entities are quite distinct from one another. Amongst intraepidermal lesions, CK20 is the most specific marker of MCC, and this can be added to the panel of diagnostic markers in the appropriate clinical setting or in difficult cases [80-82]. We have seen cases where squamous cell carcinoma in situ (SCCIS) and MCC in situ coexist, a rare and diagnostically challenging event that is easily resolved by the use of appropriate immunohistochemical panels. 
Table 3. IHC panels for spindle cell neoplasms

\begin{tabular}{|c|c|c|c|c|c|}
\hline & $\begin{array}{l}\text { Desmoplastic } \\
\text { melanoma }\end{array}$ & $\begin{array}{l}\text { SCC (PD/ } \\
\text { sarcomatoid) }\end{array}$ & AFX & Angiosarcoma & Kaposi's sarcoma \\
\hline Screening & S100 & p63 & CD10 & CD34 & HHV-8 \\
\hline$\overline{\mathrm{S} 100}$ & $\begin{array}{l}83-100 \% \\
{[26,27,192,193]}\end{array}$ & $\begin{array}{l}0 \% \\
{[192]}\end{array}$ & $\begin{array}{l}0 \% \\
{[104,192,194,195]}\end{array}$ & $\begin{array}{l}6 \% \\
{[108]}\end{array}$ & $\begin{array}{l}0 \% \\
{[196]}\end{array}$ \\
\hline HMB45 & $\begin{array}{l}0 \% \\
{[26,197]}\end{array}$ & $\begin{array}{l}0 \% \\
{[198]}\end{array}$ & $\begin{array}{l}0 \% \\
{[194,195]}\end{array}$ & $\begin{array}{l}0 \% \\
{[108,109]}\end{array}$ & - \\
\hline$\overline{\text { SOX10 }}$ & $\begin{array}{l}100 \% \\
{[25-27,31]}\end{array}$ & $\begin{array}{l}0 \% \\
{[31]}\end{array}$ & $\begin{array}{l}0 \% \\
{[25,31]}\end{array}$ & N/A & - \\
\hline$\overline{\mathrm{AE} 1 / \mathrm{AE} 3}$ & $\begin{array}{l}0 \% \\
{[192]}\end{array}$ & $\begin{array}{l}67-100 \% \\
{[105,192,199,200]}\end{array}$ & $\begin{array}{l}0 \% \\
{[105,192,194,200]}\end{array}$ & $\begin{array}{l}3-45 \% \\
{[108,113]}\end{array}$ & - \\
\hline Pan-K & $\begin{array}{l}0 \% \\
{[201]}\end{array}$ & $\begin{array}{l}40 \% \\
{[201]}\end{array}$ & $\begin{array}{l}2 \% \\
{[201]}\end{array}$ & $\begin{array}{l}35 \% \\
{[108]}\end{array}$ & - \\
\hline$\overline{p 63}$ & $\begin{array}{l}5 \% \\
{[70,102]}\end{array}$ & $\begin{array}{l}70-100 \% \\
{[102,105,199,200,} \\
201,202]\end{array}$ & $\begin{array}{l}0-20 \% \\
{[102,105,195,200-202]}\end{array}$ & $\begin{array}{l}0-22 \% \\
{[70]}\end{array}$ & $\begin{array}{l}0 \% \\
{[70]}\end{array}$ \\
\hline$\overline{\mathrm{CD} 10}$ & $\begin{array}{l}0-44 \% \\
{[102,104,192,201]}\end{array}$ & $\begin{array}{l}14-50 \% \\
{[102,192,201]}\end{array}$ & $\begin{array}{l}83-100 \% \\
{[102,104,192,201,203]}\end{array}$ & - & - \\
\hline$\overline{\text { CD34 }}$ & $\begin{array}{l}\text { See text } \\
{[204-206]}\end{array}$ & - & $\begin{array}{l}0 \% \\
{[195]}\end{array}$ & $\begin{array}{l}21-74 \% \\
{[108,110,111]}\end{array}$ & $\begin{array}{l}89-100 \% \\
{[120,207]}\end{array}$ \\
\hline$\overline{\text { ERG }}$ & - & $\begin{array}{l}0 \% \\
{[113]}\end{array}$ & $\begin{array}{l}0 \% \\
{[113,195]}\end{array}$ & $\begin{array}{l}100 \% \\
{[113]}\end{array}$ & $\begin{array}{l}92-100 \% \\
{[208,209]}\end{array}$ \\
\hline$\overline{\mathrm{CD} 31}$ & - & - & $\begin{array}{l}\text { Up to } 43 \% \\
\text { [195] }\end{array}$ & $\begin{array}{l}33-100 \% \\
{[108-112]}\end{array}$ & $\begin{array}{l}\text { HIV: } 100 \% \text { [207] } \\
\text { Non-HIV: } 83 \% \text { [207] } \\
\text { Not specified: } 84 \% \\
{[120]}\end{array}$ \\
\hline$\overline{M Y C}$ & $\begin{array}{l}5 \% \\
{[210]}\end{array}$ & - & - & $\begin{array}{l}\text { Secondary: } 100 \% \\
\text { Primary: } 0-45 \% \\
{[114-117]}\end{array}$ & $\begin{array}{l}43-54 \% \\
{[211,212]}\end{array}$ \\
\hline$\overline{\mathrm{HHV}-8}$ & - & $\begin{array}{l}0 \% \\
{[198]}\end{array}$ & - & $\begin{array}{l}0 \% \\
{[118,213,214]}\end{array}$ & $\begin{array}{l}95-100 \% \\
{[118-120]}\end{array}$ \\
\hline
\end{tabular}

Numbers in square brackets indicate references. Pan-K = Pan-keratin.

Sebaceous carcinomas (SC) can have cytomorphologic and architectural overlap with SCC, BCC, melanoma and their variants. SC, when invasive, is a more aggressive tumor than BCC and most SCC, although surgical management can be curative, making accurate diagnosis of high clinical importance. Androgen receptor (AR) is a highly sensitive marker of SC that is useful for differentiating SC from SCC or melanoma. BCCs and EMPD [83-85], however, frequently express $\mathrm{AR}$, making it a poor choice to differentiate $\mathrm{SC}$ with a similar intraepithelial pattern from these entities [83, 85-87]. More recent studies have identified adipophilin as a sensitive marker of SC, with high specificity among intraepithelial lesions, although expression in melanoma and EMPD has not been described $[83,88,89]$. Adipophilin is expressed in a membranous and vesicular pattern due to its association with membrane-bound and vesicle-laden lipids. A granular pattern of staining, sometimes present in other intraepidermal carcinomas like SCC, is not considered positive. Clear cell variants of SCC and BCC are negative for adipophilin, supporting the utility of this marker in differentiating intraepidermal carcinomas with clear cell features. The luminal cells recapitulating ductal differentiation in sweat gland neoplasms can be highlighted by CEA and/or EMA IHC stains [90], which can be helpful to distinguish the in situ component of eccrine, apocrine, and sebaceous neoplasms from EMPD or SCCIS. 
Because LCH in the adult is rarely limited to the skin, it is frequently overlooked in the differential diagnosis of intraepidermal lesions. Case reports describe instances in which LCH was mistaken for malignant melanoma due to an epithelioid cytomorphology and positivity for S100 [91], and we have also seen a case of Langerhans cell proliferation within the epidermis associated with a delayed hypersensitivity reaction (so-called Langerhans cell granulomas) mistaken for Pautrier microabscesses of mycosis fungoides, and when on nipple skin, for mammary Paget disease. Both CD1a and langerin are sensitive markers of LCH, and their use should be considered in the diagnosis of intraepidermal lesions. CD1a appears to have greater sensitivity for LCH among histiocytoses, and langerin, which correlates with the expression of Birbeck granules required to differentiate a Langerhans cell from an indeterminate cell, is of greater specificity $[92,93]$. A panel approach is recommended that includes appropriate markers of epithelial and melanocytic lineage, when the differential diagnosis includes SCCIS, EMPD, and/or Pagetoid melanoma. Because both LCH cells and malignant T cells may express CD4, pan T cell markers (e.g. CD3) should be employed when the differential diagnosis includes mycosis fungoides.

\section{Spindle Cell Tumors in the Dermis}

The differential diagnosis for spindle cell lesions in the dermis is quite broad, making IHC invaluable for classifying the many entities that may have overlapping histomorphologies. Here, we present markers used to diagnose some of the most commonly encountered tumors affecting the skin, including desmoplastic melanoma, poorly differentiated/sarcomatoid SCC, AFX, angiosarcoma (AS), and Kaposi's sarcoma (KS). Less common spindled cell tumors involving the dermis include cellular neurothekeoma with spindle cell differentiation, amelanotic cellular blue nevus [26, 94], cutaneous leiomyosarcoma/atypical intradermal smooth muscle neoplasms [95] and pleomorphic liposarcoma. In addition, exuberant formation of scar tissue is also common in the differential diagnosis, and it is worth noting that both desmoplastic melanoma and cellular scar tissue may contain cells that are immunoreactive for S100 $[26,96,97]$, and neither may stain with antibodies that generally are associated with melanocytic lineage, such as HMB-45 [26]. Markers of high utility in the accurate diagnosis of dermal spindle cell tumors (table 3), when used in the proper clinical context and in the form of well-selected panels, include keratins (pan-keratin, HMWCK), p63, melanocytic markers (S100, MART-1, and HMB-45), desmin, SMA, and endothelial markers (CD31 and CD34).

Dermatofibroma is one of the most frequently encountered spindle cell lesions of the dermis, and when cellular, deep, or incompletely sampled, may pose vexing diagnostic challenges. CD34 is helpful in distinguishing dermatofibrosarcoma protuberans (DFSP) from DF and its variants. While DFSP often shows diffuse, strong positivity for CD34 [98, 99], DF may have focal staining at the periphery and is positive for factor XIIIa (fig. 7a-d) [99]. However, it is the CD34 negativity that is most helpful in establishing a diagnosis of an unusual or worrisome dermatofibroma because FXIIIa expression lacks specificity (and may even be expressed by stromal cells in desmoplastic melanoma [100], making overinterpretation based on its expression potentially hazardous).

In the absence of an intraepidermal component, desmoplastic melanoma can be easily overlooked or mistaken for biopsy/excisional scar, making it a frequent cause of melanomarelated litigation. The utility of SOX10 in diagnosing desmoplastic melanoma due to the paucity of sensitive and specific markers is discussed elsewhere in this article (fig. 7e-h). Although MPNST, schwannomas, and neurofibromas are positive for SOX10, data published to date suggest that most other soft tissue and dermal spindle cell tumors, including spindle 

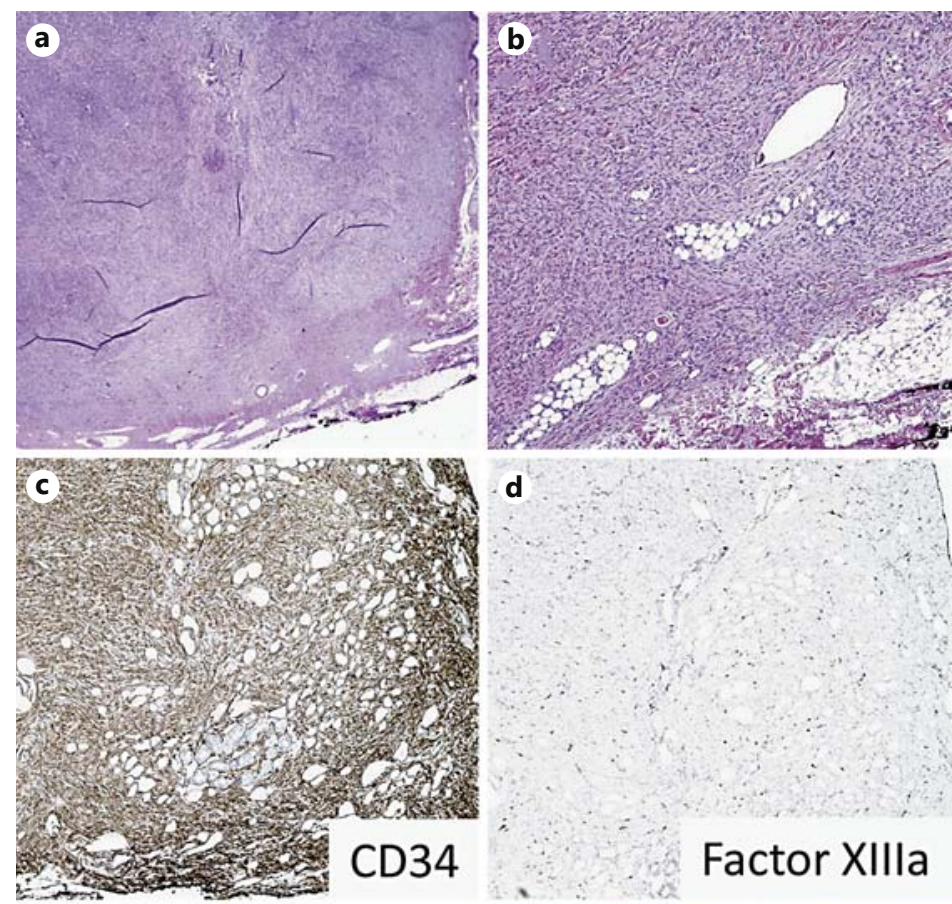

d
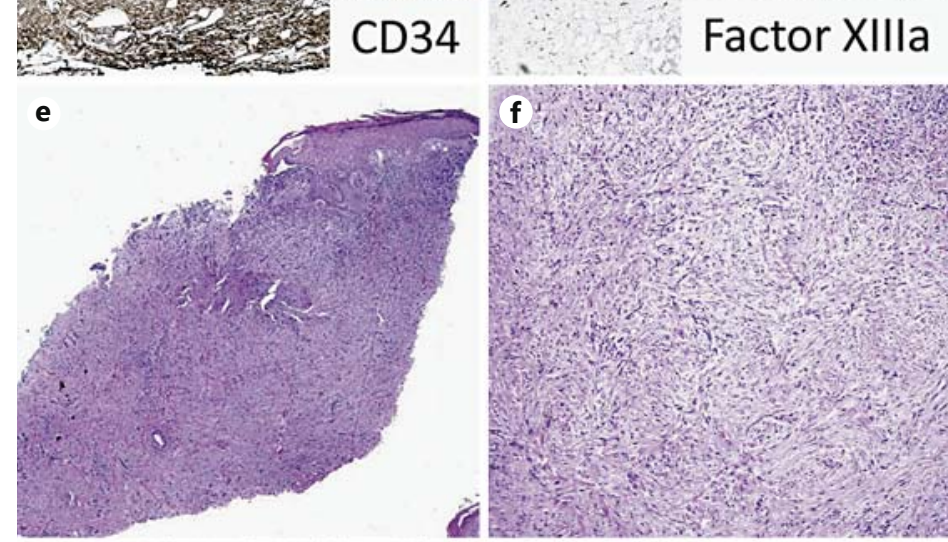

Fig. 7. IHC markers for dermal spindle cell neoplasms. a-d DFSP tumor cells are positive for CD34 (c) and negative for factor XIIIa (d). e-h Desmoplastic melanoma cells are positive for $\mathrm{S} 100(\mathbf{g})$ and SoX10 (h).

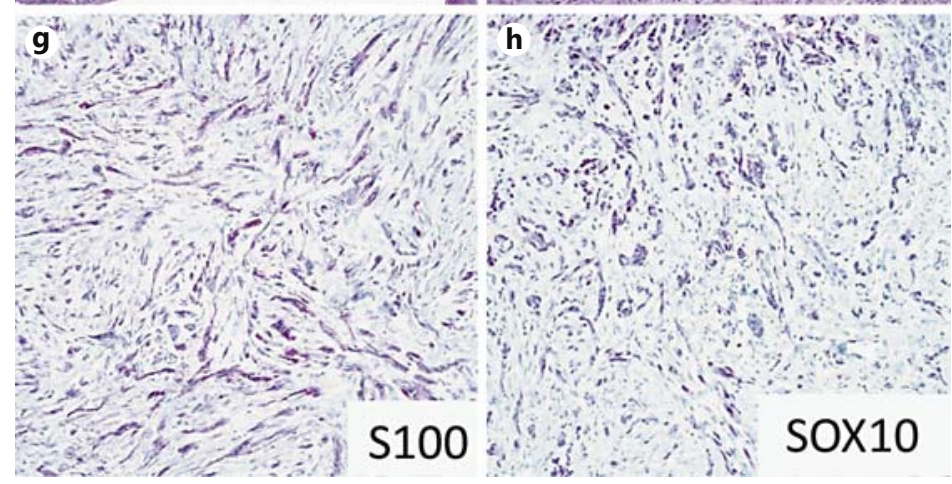

cell SCC, AFX, and DFSP are negative for SOX10 [31, 101]. Expression of SOX10 in AS and KS remains undescribed.

Immunohistochemical studies for p63 are widely regarded as useful in confirming squamous differentiation, with particular utility in the diagnostic differentiation of poorly differentiated/spindle cell variants of invasive SCC from AFX and melanoma, as well as from some mesenchymal neoplasms [70]. However, a comprehensive analysis of p63 expression 
in soft tissue neoplasms demonstrated a total lack of immunoreactivity in AS, lipomatous neoplasms, DFSP, solitary fibrous tumor, schwannoma, neurofibroma, and leiomyosarcoma [70]. Nuclear p63 reactivity was found in a subset of soft tissue neoplasms including myoepithelioma, cellular neurothekeoma, soft tissue perineurioma, Ewing's sarcoma/peripheral neuroectodermal tumor, diffuse-type giant cell tumor, and giant cell tumor of soft parts. Infrequent, weak, or focal p63 positivity was observed in low-grade fibromyxoid sarcoma, MPNST, extraskeletal myxoid chondrosarcoma, myxofibrosarcoma, proximal-type epithelioid sarcoma, synovial sarcoma, embryonal rhabdomyosarcoma, desmoplastic small round cell tumor (DSRCT), AFX, and spindle cell melanoma.

When a differential diagnosis includes melanoma, sarcomatoid SCC, and AFX, a panel of S100 and/or SOX10, cytokeratins, and p63 are useful. Within the context of this differential diagnosis, S100 is very sensitive and specific for melanoma (but not specific when other soft tissue entities enter the diagnosis). While some spindle SCCs are negative for cytokeratins, the vast majority retain expression of p63. AFX is a diagnosis of exclusion based on strict histologic criteria and negativity for keratin(s), p63, and melanocytic markers. As previously indicated, a small number of studies suggest weak focal p63 staining in AFX and melanoma $[102,103]$, although this is in sharp contrast to strong, diffuse staining seen in most SCCs. Early studies suggested that CD10 may be a sensitive marker of AFX $[102,104]$; however, this marker lacks specificity and it is not recommended for inclusion in the panel listed above $[105,106]$. Of note, KS does not express S100 or p63, although a small percentage of AS may show weak/focal positivity.

KS and AS are occasionally encountered cutaneous soft tissue malignancies [107] that may display diagnostically ambiguous spindled morphology and frequently express a variety of vascular markers including CD31, CD34, and erythroblast transformation-specific related gene (ERG). While these markers are not specific for these tumors, they may be helpful in narrowing the lineage differential among spindled cell dermal lesions. A wide range of sensitivities of CD31 and CD34 have been reported for AS; this likely relates to studies combining data for both radiation-induced and primary tumors from a variety of sites [108-112]. Limited data suggest ERG is a highly sensitive marker of both primary (non-radiation-associated) and radiation-associated AS [113]. MYC is a highly sensitive marker of radiation-associated AS that can effectively differentiate it from a primary (non-radiation-associated) AS and from atypical postradiation vascular proliferations [114-117]. KS frequently expresses ERG (92-100\%) and may also express MYC; however, it may be differentiated from AS, and from all other spindle cell and vascular neoplasms for that matter, based upon HHV-8 positivity, which is generally expressed in patch and plaque lesions, and is $100 \%$ specific, among solid tumors (HHV-8 positivity is also associated with some forms of lymphoma and Castleman's disease) [118-120]. There are limited data regarding the expression of vascular markers and MYC in SCC, AFX and melanoma, save for rare CD34 positivity in melanoma. However, it must be recalled that tumors showing the phenomenon of vasculogenic mimicry, including melanoma, may contain tumor cells that transcribe proteins encoded by certain aberrantly expresses endothelial genes, such as CD144 (VE cacherin) and TIE-1, but not CD31 [121, 122]. Indeed, multiple studies have demonstrated CD34 expression in desmoplastic melanoma, although in $>90 \%$ of cases, $<30 \%$ of tumor cells were positive.

\section{Cutaneous Adnexal Tumors}

Sclerosing adnexal tumors, particularly microcystic adnexal carcinoma (MAC), desmoplastic trichoepithelioma (DTE) and morpheaform BCC (mBCC), pose frequent diagnostic challenges due to their overlapping histologic characteristics. Differences in tumor behavior 
Table 4. IHC panels for adnexal neoplasms

\begin{tabular}{|c|c|c|c|c|}
\hline & MAC & DTE & $\mathrm{mBCC}$ & SCC \\
\hline CEA & $\begin{array}{l}44-58 \% \\
{[215,216]}\end{array}$ & $\begin{array}{l}0 \% \\
{[215,216]}\end{array}$ & $\begin{array}{l}0 \% \\
{[216]}\end{array}$ & $\begin{array}{l}0-30 \% \\
{[170,215]}\end{array}$ \\
\hline$\overline{\mathrm{D} 2-40}$ & - & $\begin{array}{l}64 \% \\
{[124]}\end{array}$ & $\begin{array}{l}6 \% \\
{[124]}\end{array}$ & $\begin{array}{l}100 \% \\
{[187]}\end{array}$ \\
\hline Ber-EP4 & $\begin{array}{l}0-38 \% \\
{[135,216,217]}\end{array}$ & $\begin{array}{l}57-75 \% \\
{[135,216,217]}\end{array}$ & $\begin{array}{l}100 \% \\
{[123,135,216,217]}\end{array}$ & $\begin{array}{l}0 \% \\
{[170]}\end{array}$ \\
\hline$\overline{\text { EMA }}$ & $\begin{array}{l}58 \% \\
{[215]}\end{array}$ & $\begin{array}{l}60 \% \\
{[215]}\end{array}$ & $\begin{array}{l}0 \% \\
{[123]}\end{array}$ & $\begin{array}{l}95 \% \\
{[170]}\end{array}$ \\
\hline $34 \mathrm{bE12}$ & - & - & - & $100 \%[170]$ \\
\hline$\overline{\mathrm{CK} 7}$ & $\begin{array}{l}100 \% \\
{[123]}\end{array}$ & $\begin{array}{l}0 \% \\
{[123]}\end{array}$ & $\begin{array}{l}0 \% \\
{[123]}\end{array}$ & $\begin{array}{l}22-40 \% \\
{[174,218]}\end{array}$ \\
\hline Cam5.2 & - & - & - & $\begin{array}{l}0 \% \\
{[174]}\end{array}$ \\
\hline$\overline{\mathrm{CK} 5 / 6}$ & $\begin{array}{l}100 \% \\
{[125]}\end{array}$ & $\begin{array}{l}100 \% \\
{[219]}\end{array}$ & $\begin{array}{l}100 \% \\
{[219]}\end{array}$ & $\begin{array}{l}70 \% \\
{[220]}\end{array}$ \\
\hline$\overline{\mathrm{CK}} 20$ & - & $\begin{array}{l}100 \%[131-133] \\
\text { (intratumoral Merkel cells) }\end{array}$ & $\begin{array}{l}0-3 \%[132,133] \\
\text { (intratumoral Merkel cells) }\end{array}$ & - \\
\hline$\overline{\text { PHLDA1 }}$ & $\begin{array}{l}40 \% \\
{[135]}\end{array}$ & $\begin{array}{l}88-100 \% \\
{[134-136]}\end{array}$ & $\begin{array}{l}0 \% \\
{[134-136]}\end{array}$ & - \\
\hline Androgen R & $\begin{array}{l}0 \% \\
{[125]}\end{array}$ & $\begin{array}{l}0-13 \% \\
{[131,132]}\end{array}$ & $\begin{array}{l}65-100 \% \\
{[131,132]}\end{array}$ & $\begin{array}{l}0-10 \% \\
{[83,85]}\end{array}$ \\
\hline$\overline{\mathrm{p} 63}$ & $\begin{array}{l}100 \% \\
{[75,125,126]}\end{array}$ & $\begin{array}{l}100 \% \\
{[126]}\end{array}$ & $\begin{array}{l}100 \% \\
{[126]}\end{array}$ & $\begin{array}{l}99-100 \% \\
{[75,187,221]}\end{array}$ \\
\hline$\overline{\mathrm{Bcl}-2}$ & $\begin{array}{l}99-100 \% \\
{[123,124]}\end{array}$ & $\begin{array}{l}0-89 \% \\
{[123,131]}\end{array}$ & $\begin{array}{l}98-100 \% \\
{[123,124127,128]}\end{array}$ & $\begin{array}{l}10-67 \% \\
{[127,129,130]}\end{array}$ \\
\hline$\overline{\mathrm{CK} 15}$ & $\begin{array}{l}10-92 \% \\
{[135,216]}\end{array}$ & $\begin{array}{l}94-100 \% \\
{[124,135,216]}\end{array}$ & $\begin{array}{l}0-64 \% \\
{[124,135,216]}\end{array}$ & $\begin{array}{l}0-3 \% \\
{[216]}\end{array}$ \\
\hline$\overline{\mathrm{CK} 17}$ & $\begin{array}{l}100 \% \\
{[125,222]}\end{array}$ & $\begin{array}{l}94-100 \% \\
{[222]}\end{array}$ & $\begin{array}{l}100 \% \\
{[223]}\end{array}$ & - \\
\hline$\overline{\text { CK19 }}$ & $\begin{array}{l}45-89 \% \\
{[135,222]}\end{array}$ & $\begin{array}{l}10-11 \% \\
{[135,222]}\end{array}$ & $\begin{array}{l}35 \% \\
{[135]}\end{array}$ & $\begin{array}{l}17 \% \\
{[224]}\end{array}$ \\
\hline
\end{tabular}

Numbers in square brackets indicate references.

(locally aggressive vs. benign) and management (wide local excision vs. conservative management) make accurate diagnosis essential, especially given the predilection of these tumors for head and neck regions where over- or undertreatment can have devastating consequences. Further, other entities, such as cutaneous SCC and metastatic carcinomas with a marked desmoplastic stromal response, enter into the differential diagnosis, with a diagnosis of the latter having critical implications for prognosis and management.

To date no immunohistochemical markers of sclerosing adnexal tumors have been described to provide sufficient sensitivity and specificity for diagnosis when the differential diagnosis is broad. Therefore, when diagnosing sclerosing adnexal tumors, or their mimics, it is best to narrow the differential diagnosis based on histologic and clinical features prior to enlisting the use of markers. Further, data regarding the utility of these markers have been inconsistent across studies. This may be partially due to instances of misdiagnosis, although it more likely relates to differences in the interpretation of 'positivity' versus 'negativity' due to variations in staining patterns, degree (percentage of labeled cells), and intensity amongst different tumor types and within a single tumor (table 4). 
A number of markers may aid in the distinction of MAC from other sclerosing lesions based on the staining pattern instead of straightforward positivity/negativity. Bcl-2 and CK7 are expressed in the central areas of individual MAC tumor nests, while peripheral cells are negative for these markers and positive for p63 [75, 123-126]. DTE, mBCC, and SCC do not display this pattern of staining and instead show either diffuse, patchy, or limited expression of these markers [127-130]. Of note, the pattern of peripheral p63 expression in MAC is more prominent with increasing tumor depth, and accordingly, the utility of this marker may be limited in superficial biopsies.

AR expression is highly specific for BCC within this differential diagnosis, but the reported sensitivity for morpheaform variants ranges from 65 to $100 \%[131,132]$. Thus, a negative result cannot rule out $\mathrm{mBCC}$. One study suggests that AR in combination with CK20 may have utility in differentiating mBCC from DTE, as CK20-positive Merkel cells frequently infiltrate DTE but are absent in mBCC [133]. However, we are unaware of the regular or reproducible utility of this panel in routine practice. Until recently, Ber-EP4 was accepted as a reliable marker for differentiating $\mathrm{mBCC}$, which is nearly always positive, from MAC, which were putatively negative. More recent data, however, suggest that up to 38\% of MACs are positive for Ber-EP4, calling into question the utility of this marker in differentiating these two morphologically similar entities. Pleckstrin homology-like domain, family A, member 1 (PHLDA1), a protein highly expressed in the hair follicle, is a more recently described marker of DTE that is not expressed in BCC, making it useful for differentiating these two entities [134-136]. Of note, up to 40\% of MACs express PHLDA1, and expression in cutaneous SCC has not been described, making interpretation difficult, if not impossible, when the differential diagnosis includes these entities. Further, mBCC may express PHLDA1 near sites involved by ulceration, making interpretation challenging in superficial biopsies showing this feature. There has been increasing interest in the use of stem cell keratins (CK15 [137, 138], CK17 [125] and CK19 [139]) for the diagnosis of sclerosing adnexal tumors, although the data remain limited and variable, and thus these markers should be used with caution.

Finally, metastatic carcinomas may histologically mimic sclerosing adnexal tumors, and the expression of IHC markers, especially keratins, in the former, varies greatly depending on tumor type (i.e. primary site/histogenesis) and degree of differentiation, creating potential diagnostic pitfalls in the diagnosis of cutaneous carcinomas. For example, cutaneous neoplasms with eccrine differentiation are often positive for estrogen receptor (ER) and/or progesterone receptor (PR) [140], and IHC is performed to predict response to hormonal therapy. The differential diagnosis of cutaneous eccrine neoplasms and metastatic breast cancer largely requires clinical and radiological correlation, since both can be positive for ER and PR [141]. Therefore, interpretation of IHC marker expression in cutaneous adnexal neoplasms should be guided by clinical and histologic features to avoid diagnostic pitfalls that could result in clinical harm.

\section{Cutaneous Small Blue Cell Neoplasms}

The differential diagnosis for small round blue cell tumors of the skin and subcutis includes primary cutaneous neoplasms (e.g. small cell variants of melanoma and adnexal carcinomas, as well as MCC), certain soft tissue neoplasms, metastatic carcinoma - particularly small cell lung carcinoma, and lymphoma. Prior to utilizing IHC to aid in the diagnosis of these entities, a differential diagnosis based on patient age, lesion location, cancer history and imaging must be formulated, given the significant overlap in marker expression within this category (table 5). 
Table 5. IHC panels for small round blue cell neoplasms

\begin{tabular}{|c|c|c|c|c|c|}
\hline & $\begin{array}{l}\text { Ewing's sarcoma/ } \\
\text { PNET }\end{array}$ & Merkel cell & Melanoma & Metastatic lung SCC & DSRCT \\
\hline Keratin & $\begin{array}{l}0-50 \% \\
{[146,149,160,225]}\end{array}$ & $\begin{array}{l}80-100 \% \\
{[79,147,226,227]}\end{array}$ & $\begin{array}{l}0-10 \% \\
{[154,161-163,228]}\end{array}$ & $\begin{array}{l}100 \% \\
{[226]}\end{array}$ & $\begin{array}{l}69-100 \% \\
{[31,32,153,159]}\end{array}$ \\
\hline$\overline{\mathrm{CK} 20}$ & $\begin{array}{l}0 \% \\
{[146]}\end{array}$ & $\begin{array}{l}75-100 \% \\
{[79,82,168,226,227,229]}\end{array}$ & $\begin{array}{l}0 \% \\
{[82,228]}\end{array}$ & $\begin{array}{l}0 \% \\
{[80]}\end{array}$ & $\begin{array}{l}0 \% \\
{[159]}\end{array}$ \\
\hline$\overline{\text { EMA }}$ & $\begin{array}{l}16 \% \\
{[160]}\end{array}$ & $\begin{array}{l}95 \% \\
{[168]}\end{array}$ & $\begin{array}{l}0-7 \% \\
{[154,161-163]}\end{array}$ & - & $\begin{array}{l}90-96 \% \\
{[151,152,159]}\end{array}$ \\
\hline$\overline{S 100}$ & $\begin{array}{l}38 \% \\
{[3]}\end{array}$ & $\begin{array}{l}17-22 \% \\
{[79,82]}\end{array}$ & $\begin{array}{l}95-100 \% \\
{[82,154,161,228]}\end{array}$ & - & $\begin{array}{l}0-13 \% \\
{[151,152]}\end{array}$ \\
\hline$\overline{\mathrm{LCA}}$ & $\begin{array}{l}0 \% \\
{[230]}\end{array}$ & $\begin{array}{l}0 \% \\
{[79]}\end{array}$ & - & - & - \\
\hline Synapto & $\begin{array}{l}23-25 \% \\
{[3,160]}\end{array}$ & $\begin{array}{l}75-96 \% \\
{[79,168,226,227]}\end{array}$ & - & $\begin{array}{l}100 \% \\
{[226]}\end{array}$ & $\begin{array}{l}15-75 \% \\
{[151,152,159]}\end{array}$ \\
\hline$\overline{\mathrm{NSE}}$ & $\begin{array}{l}36-88 \% \\
{[3]}\end{array}$ & $\begin{array}{l}100 \% \\
{[82]}\end{array}$ & $\begin{array}{l}30 \% \\
{[82]}\end{array}$ & $\begin{array}{l}58-100 \% \\
{[231-233]}\end{array}$ & $\begin{array}{l}72 \% \\
{[159]}\end{array}$ \\
\hline PAX5 & $\begin{array}{l}0 \% \\
{[234]}\end{array}$ & $\begin{array}{l}67-94 \% \\
{[226,235,236]}\end{array}$ & $\begin{array}{l}0 \% \\
{[235,237]}\end{array}$ & $\begin{array}{l}0-73 \% \\
{[226,236]}\end{array}$ & - \\
\hline $\begin{array}{l}\text { CD99 } \\
\text { (MIC2) }\end{array}$ & $\begin{array}{l}91-100 \% \\
{[3,142-149]}\end{array}$ & $\begin{array}{l}55-100 \% \\
{[168,229]}\end{array}$ & $\begin{array}{l}57-60 \% \\
{[238,239]}\end{array}$ & - & $\begin{array}{l}0-57 \% \\
{[145,151-154]}\end{array}$ \\
\hline FLI-1 & $\begin{array}{l}71-100 \% \\
{[147-150]}\end{array}$ & $\begin{array}{l}90-100 \% \\
{[155,168]}\end{array}$ & $\begin{array}{l}50-60 \% \\
{[155,239]}\end{array}$ & - & $\begin{array}{l}0-87 \% \\
{[150,155]}\end{array}$ \\
\hline TTF-1 & - & $\begin{array}{l}0-12 \% \\
{[80,147,226,227]}\end{array}$ & $\begin{array}{l}0 \% \\
{[228]}\end{array}$ & $\begin{array}{l}90-100 \% \\
{[80,169,226]}\end{array}$ & - \\
\hline NKX2.2 & $93 \%[157]$ & $\begin{array}{l}0 \% \\
{[157]}\end{array}$ & $\begin{array}{l}33 \% \\
{[157]}\end{array}$ & $\begin{array}{l}25 \% \\
{[157]}\end{array}$ & $\begin{array}{l}0 \% \\
{[157]}\end{array}$ \\
\hline
\end{tabular}

Numbers in square brackets indicate references.

Within the pediatric and young adult populations, small cell melanoma, Ewing's sarcoma/ primitive neuroectodermal tumor (PNET), DSRCT, and rhabdomyosarcoma are frequently in the differential diagnosis of small round blue cell tumors that may be present in the skin and subcutis. Unlike desmoplastic melanoma, a substantial portion of most other morphologic variants of melanoma retain expression of the more specific lineage markers MART-1, MITF, and HMB-45, making them useful in view of the lack of specificity of S100 when small cell variants of melanoma are suspected in the differential diagnosis of small round blue cell tumor. CD99 [142-149] and Friend leukemia virus integration 1 (FLI-1) [147-150] are the most sensitive markers of Ewing's sarcoma/PNET, although a substantial portion of melanomas, and by some reports, DSRCT, may express one or both of these markers $[145,150$ 155]. Further, lymphoblastic lymphoma, a hematopoietic malignancy observed in young adults, expresses CD99 and is frequently negative for leukocyte common antigen (LCA). Molecular analysis to confirm the presence of an EWS-FLI-1 fusion or the associated $t(11 ; 22)$ (q24;q12) translocation is more definitive, although a number of histologically distinct tumors are now known to be associated with this translocation, and not all Ewing's sarcoma/ PNET are positive [156]. Of note, NK2 homeobox 2 (NKX2.2) is a recently described sensitive marker of Ewing's sarcoma/PNET with greater specificity compared with CD99 and FLI-1 [157]. MostDSRCTs express EMA [152,158,159], whileEwing's sarcoma/PNET and melanoma are generally negative [154,160-163], making this a useful marker in a narrowed differential diagnosis. Finally, when rhabdomyosarcoma enters the differential diagnosis, particularly in slightly younger patient populations, myogenin and myogenic differentiation 1 are sensitive markers of this tumor, although other malignancies with rhabdoid features may also express 
these markers [164-166]. In particular, loss of SWI/SNF-related matrix-associated actindependent regulator of chromatin subfamily B, member 1 (INI-1) expression can aid in distinguishing malignant rhabdoid tumor from rhabdomyosarcoma [167].

Among older patient populations, MCC, metastatic carcinoma, lymphoma and melanoma are in the differential diagnosis of cutaneous small round blue cell tumors. Although MCC and metastatic small cell carcinoma both express neuroendocrine markers $[79,168]$, they may be differentiated in most instances based on paranuclear dot-like expression of CK20 in MCC $[79,80,82,168]$ and TTF- 1 expression in metastatic SCLC $[80,169]$. While lymphomas may have a variety of immunohistochemical profiles, most cases are distinguishable from other small round blue cell tumors based upon their expression of LCA. Of note, there are reports of lymphomas that have lost expression of LCA, again signifying the importance of utilizing a multimarker panel. Further, PAX5 (BSAP) and terminal deoxynucleotidyl transferase (TdT), two markers of some variants of lymphoma, are expressed in a portion of MCCs and thus represent a potential diagnostic pitfall [226, 227].

Finally, although rare, some sweat gland tumors may enter this differential diagnosis. While the immunophenotype among different variants of sweat gland tumors is variable, many express p63 [125], while melanoma, small cell carcinoma and soft tissue neoplasms typically do not. Of note, studies suggest some sweat gland tumors may express PAX5 [125], creating a diagnostic dilemma if lymphoma or MCC are in the differential diagnosis.

\section{Conclusion}

Herein, we have summarized the existing and more recent literature concerning the use of IHC markers in the diagnosis of cutaneous neoplasms, with specific emphasis on melanoma, epidermal tumors with intraepitheliomatous growth patterns, dermal spindle cell neoplasms, sclerosing adnexal tumors, and dermal small round blue cell tumors. IHC markers will continue to emerge in the field of diagnostic dermatopathology, especially as a result of recent rapid progress in our understanding of the genetic and epigenetic mechanisms of tumorigenesis. However, IHC must always be interpreted within an informed clinical context, a narrowed histologic differential diagnosis, a complementary panel of probes, and rigorous antibody and tissue controls to exclude false-positive and -negative interpretations.

\section{References}

1 Lian CG, Murphy GF: Histology of the skin; in Elder DE, et al (eds): Atlas and Synopsis of Lever's Histopathology of the Skin. Philadelphia, Lippincott Williams \& Wilkins, 2014, p 1544.

2 Lian CG, et al: Skin cancer; in Stewart BW, Wild CP (eds): World Cancer Report 2014. Lyon, International Agency for Research on Cancer, 2014.

-3 Banerjee SS, Harris M: Morphological and immunophenotypic variations in malignant melanoma. Histopathology 2000;36:387-402.

4 Troxel DB, Sabella JD: Problem areas in pathology practice. Uncovered by a review of malpractice claims. Am J Surg Pathol 1994;18:821-831.

5 Singh H, Sethi S, Raber M, Petersen LA: Errors in cancer diagnosis: current understanding and future directions. J Clin Oncol 2007;25:5009-5018.

6 Viray H, Bradley WR, Schalper KA, Rimm DL, Gould Rothberg BE: Marginal and joint distributions of S100, HMB-45, and Melan-A across a large series of cutaneous melanomas. Arch Pathol Lab Med 2013;137:10631073.

7 Weinstein D, Leininger J, Hamby C, Safai B: Diagnostic and prognostic biomarkers in melanoma. J Clin Aesthet Dermatol 2014; 7:13-24.

8 Maize JC Jr, Resneck JS Jr, Shapiro PE, McCalmont TH, LeBoit PE: Ducking stray 'magic bullets': a Melan-A alert. Am J Dermatopathol 2003;25:162-165. 
-9 Beltraminelli H, Shabrawi-Caelen LE, Kerl H, Cerroni L: Melan-a-positive 'pseudomelanocytic nests': a pitfall in the histopathologic and immunohistochemical diagnosis of pigmented lesions on sun-damaged skin. Am J Dermatopathol 2009;31:305-308.

10 Nybakken GE, Sargen M, Abraham R, Zhang PJ, Ming M, Xu X: MITF accurately highlights epidermal melanocytes in atypical intraepidermal melanocytic proliferations. Am J Dermatopathol 2013;35:25-29.

11 Dean NR, Brennan J, Haynes J, Goddard C, Cooter RD: Immunohistochemical labeling of normal melanocytes. Appl Immunohistochem Mol Morphol 2002;10:199-204.

12 Banerjee SS, Eyden B: Divergent differentiation in malignant melanomas: a review. Histopathology 2008;52: 119-129.

13 Jalas JR, Vemula S, Bezrookove V, Leboit PE, Simko JP, Bastian BC: Metastatic melanoma with striking adenocarcinomatous differentiation illustrating phenotypic plasticity in melanoma. Am J Surg Pathol 2011;35: 1413-1418.

14 Morimoto A, Asai J, Wakabayashi Y, Komori S, Hanada K, Takenaka H, Konishi E, Katoh N: Malignant melanoma with probable smooth muscle differentiation. Case Rep Dermatol 2014;6:16-19.

15 Balch CM, Gershenwald JE, Soong SJ, Thompson JF, Atkins MB, Byrd DR, Buzaid AC, Cochran AJ, Coit DG, Ding S, Eggermont AM, Flaherty KT, Gimotty PA, Kirkwood JM, McMasters KM, Mihm MC Jr, Morton DL, Ross MI, Sober AJ, Sondak VK: Final version of 2009 AJCC melanoma staging and classification. J Clin Oncol 2009;27: 6199-6206.

16 Tetzlaff MT, Curry JL, Ivan D, Wang WL, Torres-Cabala CA, Bassett RL, Valencia KM, McLemore MS, Ross MI, Prieto VG: Immunodetection of phosphohistone H3 as a surrogate of mitotic figure count and clinical outcome in cutaneous melanoma. Mod Pathol 2013;26:1153-1160.

17 Schimming TT, Grabellus F, Roner M, Pechlivanis S, Sucker A, Bielefeld N, Moll I, Schadendorf D, Hillen U: pHH3 immunostaining improves interobserver agreement of mitotic index in thin melanomas. Am J Dermatopathol 2012;34:266-269.

18 Ikenberg K, Pfaltz M, Rakozy C, Kempf W: Immunohistochemical dual staining as an adjunct in assessment of mitotic activity in melanoma. J Cutan Pathol 2012;39:324-330.

19 Ladstein RG, Bachmann IM, Straume 0, Akslen LA: Ki-67 expression is superior to mitotic count and novel proliferation markers PHH3, MCM4 and mitosin as a prognostic factor in thick cutaneous melanoma. BMC Cancer 2010;10:140.

-20 Nielsen PS, Riber-Hansen R, Jensen TO, Schmidt H, Steiniche T: Proliferation indices of phosphohistone H3 and Ki67: strong prognostic markers in a consecutive cohort with stage I/II melanoma. Mod Pathol 2013;26:404413.

21 Ladstein RG, Bachmann IM, Straume 0, Akslen LA: Prognostic importance of the mitotic marker phosphohistone H3 in cutaneous nodular melanoma. J Invest Dermatol 2012;132:1247-1252.

-22 Miller DD, Emley A, Yang S, Richards JE, Lee JE, Deng A, Hoang MP, Mahalingam M: Mixed versus pure variants of desmoplastic melanoma: a genetic and immunohistochemical appraisal. Mod Pathol 2012;25:505-515.

-23 Ohsie SJ, Sarantopoulos GP, Cochran AJ, Binder SW: Immunohistochemical characteristics of melanoma. J Cutan Pathol 2008;35:433-444.

24 Harris ML, Baxter LL, Loftus SK, Pavan WJ: Sox proteins in melanocyte development and melanoma. Pigment Cell Melanoma Res 2010;23:496-513.

25 Shin J, Vincent JG, Cuda JD, Xu H, Kang S, Kim J, Taube JM: Sox10 is expressed in primary melanocytic neoplasms of various histologies but not in fibrohistiocytic proliferations and histiocytoses. J Am Acad Dermatol 2012; 67:717-726.

-26 Ramos-Herberth FI, Karamchandani J, Kim J, Dadras SS: SOX10 immunostaining distinguishes desmoplastic melanoma from excision scar. J Cutan Pathol 2010;37:944-952.

27 Nonaka D, Chiriboga L, Rubin BP: Sox10: a pan-schwannian and melanocytic marker. Am J Surg Pathol 2008; 32:1291-1298.

28 Cimino-Mathews A, Subhawong AP, Elwood H, Warzecha HN, Sharma R, Park BH, Taube JM, Illei PB, Argani P: Neural crest transcription factor Sox10 is preferentially expressed in triple-negative and metaplastic breast carcinomas. Hum Pathol 2013;44:959-965.

29 Ohtomo R, Mori T, Shibata S, Tsuta K, Maeshima AM, Akazawa C, Watabe Y, Honda K, Yamada T, Yoshimoto S, Asai M, Okano H, Kanai Y, Tsuda H: SOX10 is a novel marker of acinus and intercalated duct differentiation in salivary gland tumors: a clue to the histogenesis for tumor diagnosis. Mod Pathol 2013;26:1041-1050.

- 30 Ivanov SV, Panaccione A, Nonaka D, Prasad ML, Boyd KL, Brown B, Guo Y, Sewell A, Yarbrough WG: Diagnostic SOX10 gene signatures in salivary adenoid cystic and breast basal-like carcinomas. Br J Cancer 2013;109: 444-451.

31 Palla B, Su A, Binder S, Dry S: SoX10 expression distinguishes desmoplastic melanoma from its histologic mimics. Am J Dermatopathol 2013;35:576-581.

32 Hisaoka M, Ishida T, Kuo TT, Matsuyama A, Imamura T, Nishida K, Kuroda H, Inayama Y, Oshiro H, Kobayashi H, Nakajima T, Fukuda T, Ae K, Hashimoto H: Clear cell sarcoma of soft tissue: a clinicopathologic, immunohistochemical, and molecular analysis of 33 cases. Am J Surg Pathol 2008;32:452-460.

-33 Hantschke M, Mentzel T, Rutten A, Palmedo G, Calonje E, Lazar AJ, Kutzner H: Cutaneous clear cell sarcoma: a clinicopathologic, immunohistochemical, and molecular analysis of 12 cases emphasizing its distinction from dermal melanoma. Am J Surg Pathol 2010;34:216-222. 
-34 Davis IJ, Kim JJ, Ozsolak F, Widlund HR, Rozenblatt-Rosen O, Granter SR, Du J, Fletcher JA, Denny CT, Lessnick SL, Linehan WM, Kung AL, Fisher DE: Oncogenic MITF dysregulation in clear cell sarcoma: defining the MiT family of human cancers. Cancer Cell 2006;9:473-484.

35 Wang WL, Mayordomo E, Zhang W, Hernandez VS, Tuvin D, Garcia L, Lev DC, Lazar AJ, Lopez-Terrada D: Detection and characterization of EWSR1/ATF1 and EWSR1/CREB1 chimeric transcripts in clear cell sarcoma (melanoma of soft parts). Mod Pathol 2009;22:1201-1209.

-36 Hodis E, Watson IR, Kryukov GV, Arold ST, et al: A landscape of driver mutations in melanoma. Cell 2012;150 251-263.

-37 Edlundh-Rose E, Egyhazi S, Omholt K, Mansson-Brahme E, Platz A, Hansson J, Lundeberg J: NRAS and BRAF mutations in melanoma tumours in relation to clinical characteristics: a study based on mutation screening by pyrosequencing. Melanoma Res 2006;16:471-478.

-38 Fisher KE, Cohen C, Siddiqui MT, Palma JF, Lipford EH 3rd, Longshore JW: Accurate detection of BRAF p.V600E mutations in challenging melanoma specimens requires stringent immunohistochemistry scoring criteria or sensitive molecular assays. Hum Pathol 2014;45:2281-2293.

-39 Pearlstein MV, Zedek DC, Ollila DW, Treece A, Gulley ML, Groben PA, Thomas NE: Validation of the VE1 immunostain for the BRAF V600E mutation in melanoma. J Cutan Pathol 2014;41:724-732.

40 Just PA, Audebourg A, Pasmant E, Clauser E, Carlotti A, Laurent S, Avril MF, Vacher-Lavenu MC, Vidaud M, Terris B: Immunohistochemistry versus next-generation sequencing for the routine detection of BRAF V600E mutation in melanomas. Hum Pathol 2014;45:1983-1984.

-41 Massi D, Simi L, Sensi E, Baroni G, Xue G, Scatena C, Caldarella A, Pinzani P, Fontanini G, Carobbio A, Urso C, Mandala M: Immunohistochemistry is highly sensitive and specific for the detection of NRASQ61R mutation in melanoma. Mod Pathol 2014, Epub ahead of print.

42 Murali R, Wiesner T, Scolyer RA: Tumours associated with BAP1 mutations. Pathology 2013;45:116-126. van Essen TH, van Pelt SI, Versluis M, Bronkhorst IH, van Duinen SG, Marinkovic M, Kroes WG, Ruivenkamp CA, de Klein A, Kilic E, Harbour JW, Luyten GP, van der Velden PA, Verdijk RM, Jager MJ: Prognostic parameters in uveal melanoma and their association with BAP1 expression. Br J Ophthalmol 2014;98:1738-1743.

-44 Wiesner T, Murali R, Fried I, Cerroni L, Busam K, Kutzner H, Bastian BC: A distinct subset of atypical Spitz tumors is characterized by BRAF mutation and loss of BAP1 expression. Am J Surg Pathol 2012;36:818-830.

45 Lian CG, Xu Y, Ceol C, Wu F, et al: Loss of 5-hydroxymethylcytosine is an epigenetic hallmark of melanoma. Cell 2012;150:1135-1146.

46 Larson AR, Dresser KA, Zhan Q, Lezcano C, Woda BA, Yosufi B, Thompson JF, Scolyer RA, Mihm MC Jr, Shi YG, Murphy GF, Lian CG: Loss of 5-hydroxymethylcytosine correlates with increasing morphologic dysplasia in melanocytic tumors. Mod Pathol 2014;27:936-944.

47 Gambichler T, Sand M, Skrygan M: Loss of 5-hydroxymethylcytosine and ten-eleven translocation 2 protein expression in malignant melanoma. Melanoma Res 2013;23:218-220.

48 Uchiyama R, Uhara H, Uchiyama A, Ogawa E, Takazawa Y, Ashida A, Koga H, Hayashi K, Kiniwa Y, Okuyama R: 5-Hydroxymethylcytosine as a useful marker to differentiate between malignant melanomas and benign melanocytic nevi. J Dermatol Sci 2014;73:161-163.

-49 Lee JJ, Granter SR, Laga AC, Saavedra AP, Zhan Q, Guo W, Xu S, Murphy GF, Lian CG: 5-Hydroxymethylcytosine expression in metastatic melanoma versus nodal nevus in sentinel lymph node biopsies. Mod Pathol 2015;28: 218-229.

50 Han H, Cortez CC, Yang X, Nichols PW, Jones PA, Liang G: DNA methylation directly silences genes with non-CpG island promoters and establishes a nucleosome occupied promoter. Hum Mol Genet 2011;20:4299-4310.

51 Zhang Z, Chen G, Cheng Y, Martinka M, Li G: Prognostic significance of RUNX3 expression in human melanoma. Cancer 2011;117:2719-2727.

52 Gambichler T, Rotterdam S, Radkowski K, Altmeyer P, Kreuter A: Differential expression of microtubule-associated protein 2 in melanocytic skin lesions. Am J Clin Pathol 2009;131:710-714.

53 Mourmouras V, Cevenini G, Cosci E, Epistolato MC, Biagioli M, Barbagli L, Luzi P, Mannucci S, Miracco C: Nucleolin protein expression in cutaneous melanocytic lesions. J Cutan Pathol 2009;36:637-646.

54 Lade-Keller J, Riber-Hansen R, Guldberg P, Schmidt H, Hamilton-Dutoit SJ, Steiniche T: Immunohistochemical analysis of molecular drivers in melanoma identifies p16 as an independent prognostic biomarker. J Clin Pathol 2014;67:520-528.

-55 Laga AC, Zhan Q, Weishaupt C, Ma J, Frank MH, Murphy GF: SOX2 and nestin expression in human melanoma: an immunohistochemical and experimental study. Exp Dermatol 2011;20:339-345.

56 Girouard SD, Laga AC, Mihm MC, Scolyer RA, Thompson JF, Zhan Q, Widlund HR, Lee CW, Murphy GF: SOX2 contributes to melanoma cell invasion. Lab Invest 2012;92:362-370.

57 Chen PL, Chen WS, Li J, Lind AC, Lu D: Diagnostic utility of neural stem and progenitor cell markers nestin and SOX2 in distinguishing nodal melanocytic nevi from metastatic melanomas. Mod Pathol 2013;26:44-53.

58 Massi D, Brusa D, Merelli B, Ciano M, Audrito V, Serra S, Buonincontri R, Baroni G, Nassini R, Minocci D, Cattaneo L, Tamborini E, Carobbio A, Rulli E, Deaglio S, Mandala M: PD-L1 marks a subset of melanomas with a shorter overall survival and distinct genetic and morphological characteristics. Ann Oncol 2014;25:2433-2442.

59 Philips GK, Atkins M: Therapeutic uses of anti-PD-1 and anti-PD-L1 antibodies. Int Immunol 2015;27:39-46.

-60 Berghoff AS, Ricken G, Widhalm G, Rajky 0, Dieckmann K, Birner P, Bartsch R, Holler C, Preusser M: Tumourinfiltrating lymphocytes and expression of programmed death ligand 1 (PD-L1) in melanoma brain metastases. Histopathology 2015;66:289-299. 
61 Hodi FS, Lawrence D, Lezcano C, Wu X, et al: Bevacizumab plus ipilimumab in patients with metastatic melanoma. Cancer Immunol Res 2014;2:632-642.

-62 Straussman R, Morikawa T, Shee K, Barzily-Rokni M, Qian ZR, Du J, Davis A, Mongare MM, Gould J, Frederick DT, Cooper ZA, Chapman PB, Solit DB, Ribas A, Lo RS, Flaherty KT, Ogino S, Wargo JA, Golub TR: Tumour microenvironment elicits innate resistance to RAF inhibitors through HGF secretion. Nature 2012;487:500-504.

-63 Lezcano C, Lee CW, Larson AR, Menzies AM, Kefford RF, Thompson JF, Mihm MC Jr, Ogino S, Long GV, Scolyer RA, Murphy GF: Evaluation of stromal HGF immunoreactivity as a biomarker for melanoma response to RAF inhibitors. Mod Pathol 2014;27:1193-1202.

64 Alhumaidi A: Practical immunohistochemistry of epithelial skin tumor. Ind J Dermatol Venereol Leprol 2012; 78:698-708.

65 Du X, Yin X, Zhou N, Zhang G, Shi H, Cao S: Extramammary Paget's disease mimicking acantholytic squamous cell carcinoma in situ: a case report. J Cutan Pathol 2010;37:683-686.

66 Lau J, Kohler S: Keratin profile of intraepidermal cells in Paget's disease, extramammary Paget's disease, and pagetoid squamous cell carcinoma in situ. J Cutan Pathol 2003;30:449-454.

67 Hida T, Yoneta A, Nishizaka T, Ohmura T, Suzuki Y, Kameshima H, Yamashita T: Pigmented mammary Paget's disease mimicking melanoma: report of three cases. Eur J Dermatol 2012;22:121-124.

68 Hilliard NJ, Huang C, Andea A: Pigmented extramammary Paget's disease of the axilla mimicking melanoma: case report and review of the literature. J Cutan Pathol 2009;36:995-1000.

69 Raju RR, Goldblum JR, Hart WR: Pagetoid squamous cell carcinoma in situ (pagetoid Bowen's disease) of the external genitalia. Int J Gynecol Pathol 2003;22:127-135.

70 Jo VY, Fletcher CD: p63 immunohistochemical staining is limited in soft tissue tumors. Am J Clin Pathol 2011; 136:762-766.

71 Yao JY, Chen JK: Roles of p63 in epidermal development and tumorigenesis. Biomed J 2012;35:457-463.

-72 Orzol P, Nekulova M, Vojtesek B, Holcakova J: P63 - an important player in epidermal and tumour development. Klin Onkol 2012;25(suppl 2):2S11-2S15.

73 Reis-Filho JS, Torio B, Albergaria A, Schmitt FC: p63 expression in normal skin and usual cutaneous carcinomas. J Cutan Pathol 2002;29:517-523.

74 Park HR, Min SK, Cho HD, Kim KH, Shin HS, Park YE: Expression profiles of p63, p53, survivin, and hTERT in skin tumors. J Cutan Pathol 2004;31:544-549.

75 Sakiz D, Turkmenoglu TT, Kabukcuoglu F: The expression of p63 and p53 in keratoacanthoma and intraepidermal and invasive neoplasms of the skin. Pathol Res Pract 2009;205:589-594.

-76 Memezawa A, Okuyama R, Tagami H, Aiba S: p63 constitutes a useful histochemical marker for differentiation of pagetoid Bowen's disease from extramammary Paget's disease. Acta Derm Venereol 2008;88:619-620.

$\checkmark 77$ Chen S, Moroi Y, Urabe K, Takeuchi S, Kido M, Hayashida S, Uchi H, Uenotsuchi T, Tu Y, Furue M: Differential expression of two new members of the p53 family, p63 and p73, in extramammary Paget's disease. Clin Exp Dermatol 2008;33:634-640.

-78 Sellheyer K, Krahl D: Ber-EP4 enhances the differential diagnostic accuracy of cytokeratin 7 in pagetoid cutaneous neoplasms. J Cutan Pathol 2008;35:366-372.

-79 Acebo E, Vidaurrazaga N, Varas C, Burgos-Bretones JJ, Diaz-Perez JL: Merkel cell carcinoma: a clinicopathological study of 11 cases. J Eur Acad Dermatol Venereol 2005;19:546-551.

-80 Leech SN, Kolar AJ, Barrett PD, Sinclair SA, Leonard N: Merkel cell carcinoma can be distinguished from metastatic small cell carcinoma using antibodies to cytokeratin 20 and thyroid transcription factor 1. J Clin Pathol 2001;54:727-729.

81 D'Agostino M, Cinelli C, Willard R, Hofmann J, Jellinek N, Robinson-Bostom L: Epidermotropic Merkel cell carcinoma: a case series with histopathologic examination. J Am Acad Dermatol 2010;62:463-468.

-82 Kontochristopoulos GJ, Stavropoulos PG, Krasagakis K, Goerdt S, Zouboulis CC: Differentiation between Merkel cell carcinoma and malignant melanoma: an immunohistochemical study. Dermatology 2000;201:123-126.

83 Ansai S, Takeichi H, Arase S, Kawana S, Kimura T: Sebaceous carcinoma: an immunohistochemical reappraisal. Am J Dermatopathol 2011;33:579-587.

84 Asadi-Amoli F, Khoshnevis F, Haeri H, Jahanzad I, Pazira R, Shahsiah R: Comparative examination of androgen receptor reactivity for differential diagnosis of sebaceous carcinoma from squamous cell and basal cell carcinoma. Am J Clin Pathol 2010;134:22-26.

85 Bayer-Garner IB, Givens V, Smoller B: Immunohistochemical staining for androgen receptors: a sensitive marker of sebaceous differentiation. Am J Dermatopathol 1999;21:426-431.

86 Inoguchi N, Matsumura Y, Kanazawa N, Morita K, Tachibana T, Sakurai T, Utani A, Miyachi Y: Expression of prostate-specific antigen and androgen receptor in extramammary Paget's disease and carcinoma. Clin Exp Dermatol 2007;32:91-94.

87 Liegl B, Horn LC, Moinfar F: Androgen receptors are frequently expressed in mammary and extramammary Paget's disease. Mod Pathol 2005;18:1283-1288.

-88 Ostler DA, Prieto VG, Reed JA, Deavers MT, Lazar AJ, Ivan D: Adipophilin expression in sebaceous tumors and other cutaneous lesions with clear cell histology: an immunohistochemical study of 117 cases. Mod Pathol 2010;23:567-573.

89 Muthusamy K, Halbert G, Roberts F: Immunohistochemical staining for adipophilin, perilipin and TIP47. J Clin Pathol 2006;59:1166-1170. 
90 Robson A, Greene J, Ansari N, Kim B, Seed PT, McKee PH, Calonje E: Eccrine porocarcinoma (malignant eccrine poroma): a clinicopathologic study of 69 cases. Am J Surg Pathol 2001;25:710-720.

91 Billings TL, Barr R, Dyson S: Langerhans cell histiocytosis mimicking malignant melanoma: a diagnostic pitfall. Am J Dermatopathol 2008;30:497-499.

-92 Lau SK, Chu PG, Weiss LM: Immunohistochemical expression of Langerin in Langerhans cell histiocytosis and non-Langerhans cell histiocytic disorders. Am J Surg Pathol 2008;32:615-619.

93 Azumi N, Sheibani K, Swartz WG, Stroup RM, Rappaport H: Antigenic phenotype of Langerhans cell histiocytosis: an immunohistochemical study demonstrating the value of LN-2, LN-3, and vimentin. Hum Pathol 1988; 19:1376-1382.

-94 Zembowicz A, Granter SR, McKee PH, Mihm MC: Amelanotic cellular blue nevus: a hypopigmented variant of the cellular blue nevus: clinicopathologic analysis of 20 cases. Am J Surg Pathol 2002;26:1493-1500.

-95 Kraft S, Fletcher CD: Atypical intradermal smooth muscle neoplasms: clinicopathologic analysis of 84 cases and a reappraisal of cutaneous 'leiomyosarcoma'. Am J Surg Pathol 2011;35:599-607.

-96 Robson A, Allen P, Hollowood K: S100 expression in cutaneous scars: a potential diagnostic pitfall in the diagnosis of desmoplastic melanoma. Histopathology 2001;38:135-140.

-97 Chorny JA, Barr RJ: S100-positive spindle cells in scars: a diagnostic pitfall in the re-excision of desmoplastic melanoma. Am J Dermatopathol 2002;24:309-312.

98 Mentzel T, Beham A, Katenkamp D, Dei Tos AP, Fletcher CD: Fibrosarcomatous ('high-grade') dermatofibrosarcoma protuberans: clinicopathologic and immunohistochemical study of a series of 41 cases with emphasis on prognostic significance. Am J Surg Pathol 1998;22:576-587.

99 Goldblum JR, Tuthill RJ: CD34 and factor-XIIIa immunoreactivity in dermatofibrosarcoma protuberans and dermatofibroma. Am J Dermatopathol 1997;19:147-153.

100 Carlson JA, Dickersin GR, Sober AJ, Barnhill RL: Desmoplastic neurotropic melanoma. A clinicopathologic analysis of 28 cases. Cancer 1995; 75:478-494.

101 Karamchandani Jr, Nielsen T0, van de Rijn M, West RB: Sox10 and S100 in the diagnosis of soft-tissue neoplasms. Appl Immunohistochem Mol Morphol 2012; 20: 445-450.

102 Kanner WA, Brill LB 2nd, Patterson JW, Wick MR: CD10, p63 and CD99 expression in the differential diagnosis of atypical fibroxanthoma, spindle cell squamous cell carcinoma and desmoplastic melanoma. J Cutan Pathol 2010;37:744-750.

103 Matin RN, Chikh A, Chong SL, Mesher D, Graf M, Sanza P, Senatore V, Scatolini M, Moretti F, Leigh IM, Proby CM, Costanzo A, Chiorino G, Cerio R, Harwood CA, Bergamaschi D: p63 is an alternative p53 repressor in melanoma that confers chemoresistance and a poor prognosis. J Exp Med 2013;210:581-603.

104 de Feraudy S, Mar N, McCalmont TH: Evaluation of CD10 and procollagen 1 expression in atypical fibroxanthoma and dermatofibroma. Am J Surg Pathol 2008;32:1111-1122.

105 Hall JM, Saenger JS, Fadare 0: Diagnostic utility of P63 and CD10 in distinguishing cutaneous spindle cell/ sarcomatoid squamous cell carcinomas and atypical fibroxanthomas. Int J Clin Exp Pathol 2008;1:524-530.

106 Wieland CN, Dyck R, Weenig RH, Comfere NI: The role of CD10 in distinguishing atypical fibroxanthoma from sarcomatoid (spindle cell) squamous cell carcinoma. J Cutan Pathol 2011;38:884-888.

107 Rouhani P, Fletcher CD, Devesa SS, Toro JR: Cutaneous soft tissue sarcoma incidence patterns in the US: an analysis of 12,114 cases. Cancer 2008;113:616-627.

108 Meis-Kindblom JM, Kindblom LG: Angiosarcoma of soft tissue: a study of 80 cases. Am J Surg Pathol 1998;22: 683-697.

109 Ohsawa M, Naka N, Tomita Y, Kawamori D, Kanno H, Aozasa K: Use of immunohistochemical procedures in diagnosing angiosarcoma. Evaluation of 98 cases. Cancer 1995;75:2867-2874.

110 Donghi D, Kerl K, Dummer R, Schoenewolf N, Cozzio A: Cutaneous angiosarcoma: own experience over 13 years. Clinical features, disease course and immunohistochemical profile. J Eur Acad Dermatol Venereol 2010; 24:1230-1234

111 Orchard GE, Zelger B, Jones EW, Jones RR: An immunocytochemical assessment of 19 cases of cutaneous angiosarcoma. Histopathology 1996;28:235-240.

112 DeYoung BR, Swanson PE, Argenyi ZB, Ritter JH, Fitzgibbon JF, Stahl DJ, Hoover W, Wick MR: CD31 immunoreactivity in mesenchymal neoplasms of the skin and subcutis: report of 145 cases and review of putative immunohistologic markers of endothelial differentiation. J Cutan Pathol 1995;22:215-222.

113 McKay KM, Doyle LA, Lazar AJ, Hornick JL: Expression of ERG, an Ets family transcription factor, distinguishes cutaneous angiosarcoma from histological mimics. Histopathology 2012;61:989-991.

114 Fernandez AP, Sun Y, Tubbs RR, Goldblum JR, Billings SD: FISH for MYC amplification and anti-MYC immunohistochemistry: useful diagnostic tools in the assessment of secondary angiosarcoma and atypical vascular proliferations. J Cutan Pathol 2012;39:234-242.

115 Ginter PS, Mosquera JM, Macdonald TY, D’Alfonso TM, Rubin MA, Shin SJ: Diagnostic utility of MYC amplification and anti-MYC immunohistochemistry in atypical vascular lesions, primary or radiation-induced mammary angiosarcomas, and primary angiosarcomas of other sites. Hum Pathol 2014;45:709-716.

116 Guo T, Zhang L, Chang NE, Singer S, Maki RG, Antonescu CR: Consistent MYC and FLT4 gene amplification in radiation-induced angiosarcoma but not in other radiation-associated atypical vascular lesions. Genes Chromosomes Cancer 2011;50:25-33. 
117 Mentzel T, Schildhaus HU, Palmedo G, Buttner R, Kutzner H: Postradiation cutaneous angiosarcoma after treatment of breast carcinoma is characterized by MYC amplification in contrast to atypical vascular lesions after radiotherapy and control cases: clinicopathological, immunohistochemical and molecular analysis of 66 cases. Mod Pathol 2012;25:75-85.

118 Robin YM, Guillou L, Michels JJ, Coindre JM: Human herpesvirus 8 immunostaining: a sensitive and specific method for diagnosing Kaposi sarcoma in paraffin-embedded sections. Am J Clin Pathol 2004;121:330-334.

119 Pereira PF, Cuzzi T, Galhardo MC: Immunohistochemical detection of the latent nuclear antigen-1 of the human herpesvirus type 8 to differentiate cutaneous epidemic Kaposi sarcoma and its histological simulators. An Bras Dermatol 2013;88:243-246.

120 Wada DA, Perkins SL, Tripp S, Coffin CM, Florell SR: Human herpesvirus 8 and iron staining are useful in differentiating Kaposi sarcoma from interstitial granuloma annulare. Am J Clin Pathol 2007;127:263-270.

121 Hendrix MJ, Seftor EA, Hess AR, Seftor RE: Vasculogenic mimicry and tumour-cell plasticity: lessons from melanoma. Nat Rev Cancer 2003;3:411-421.

122 Lezcano C, Kleffel S, Lee N, Larson AR, Zhan Q, DoRosario A, Wang LC, Schatton T, Murphy GF: Merkel cell carcinoma expresses vasculogenic mimicry: demonstration in patients and experimental manipulation in xenografts. Lab Invest 2014;94:1092-1102.

123 Smith KJ, Williams J, Corbett D, Skelton H: Microcystic adnexal carcinoma: an immunohistochemical study including markers of proliferation and apoptosis. Am J Surg Pathol 2001;25:464-471.

124 Tebcherani AJ, de Andrade HF Jr, Sotto MN: Diagnostic utility of immunohistochemistry in distinguishing trichoepithelioma and basal cell carcinoma: evaluation using tissue microarray samples. Mod Pathol 2012;25: 1345-1353.

125 Rollins-Raval M, Chivukula M, Tseng GC, Jukic D, Dabbs DJ: An immunohistochemical panel to differentiate metastatic breast carcinoma to skin from primary sweat gland carcinomas with a review of the literature. Arch Pathol Lab Med 2011;135:975-983.

126 Vidal CI, Goldberg M, Burstein DE, Emanuel HJ, Emanuel PO: p63 immunohistochemistry is a useful adjunct in distinguishing sclerosing cutaneous tumors. Am J Dermatopathol 2010;32:257-261.

127 Morales-Ducret CR, van de Rijn M, LeBrun DP, Smoller BR: bcl-2 expression in primary malignancies of the skin. Arch Dermatol 1995;131:909-912.

128 Mateoiu C, Pirici A, Bogdan F: Immunohistochemical nuclear staining for p53, PCNA, Ki-67 and bcl-2 in different histologic variants of basal cell carcinoma. Rom J Morphol Embryol 2011;52:315-319.

129 Stanimirovic A, Cupic H, Bosnjak B, Tomas D, Kruslin B, Belicza M: TP53, Bcl-2 and growth hormone receptor expression in cutaneous squamous cell carcinoma. Acta Dermatovenerol Croat 2005;13:201-205.

130 Abu Juba B, Sovrea A, Crisan D, Melincovici C, Coneac A, Badea M, Crisan M: Apoptotic markers in photoinduced cutaneous carcinoma. Rom J Morphol Embryol 2013;54:741-747.

131 Costache M, Bresch M, Boer A: Desmoplastic trichoepithelioma versus morphoeic basal cell carcinoma: a critical reappraisal of histomorphological and immunohistochemical criteria for differentiation. Histopathology 2008;52:865-876.

132 Katona TM, Perkins SM, Billings SD: Does the panel of cytokeratin 20 and androgen receptor antibodies differentiate desmoplastic trichoepithelioma from morpheaform/infiltrative basal cell carcinoma? J Cutan Pathol 2008;35:174-179.

133 Hartschuh W, Schulz T: Merkel cells are integral constituents of desmoplastic trichoepithelioma: an immunohistochemical and electron microscopic study. J Cutan Pathol 1995;22:413-421.

134 Sellheyer K, Krahl D: PHLDA1 (TDAG51) is a follicular stem cell marker and differentiates between morphoeic basal cell carcinoma and desmoplastic trichoepithelioma. Br J Dermatol 2011;164:141-147.

135 Sellheyer K, Nelson P, Kutzner H, Patel RM: The immunohistochemical differential diagnosis of microcystic adnexal carcinoma, desmoplastic trichoepithelioma and morpheaform basal cell carcinoma using BerEP4 and stem cell markers. J Cutan Pathol 2013;40:363-370.

136 Yeh I, McCalmont TH, LeBoit PE: Differential expression of PHLDA1 (TDAG51) in basal cell carcinoma and trichoepithelioma. Br J Dermatol 2012;167:1106-1110.

137 Mahalingam M, Nguyen LP, Richards JE, Muzikansky A, Hoang MP: The diagnostic utility of immunohistochemistry in distinguishing primary skin adnexal carcinomas from metastatic adenocarcinoma to skin: an immunohistochemical reappraisal using cytokeratin 15, nestin, p63, D2-40, and calretinin. Mod Pathol 2010;23:713-719.

138 Mahalingam M, Srivastava A, Hoang MP: Expression of stem-cell markers (cytokeratin 15 and nestin) in primary adnexal neoplasms-clues to etiopathogenesis. Am J Dermatopathol 2010;32:774-779.

139 Fernandez-Flores A: Immunohistochemical and morphologic evaluation of primary cutaneous apocrine carcinomas and cutaneous metastases from ductal breast carcinoma. Rom J Morphol Embryol 2012;53:879-892.

140 Busam KJ, Tan LK, Granter SR, Kohler S, Junkins-Hopkins J, Berwick M, Rosen PP: Epidermal growth factor, estrogen, and progesterone receptor expression in primary sweat gland carcinomas and primary and metastatic mammary carcinomas. Mod Pathol 1999;12:786-793.

141 Wallace ML, Longacre TA, Smoller BR: Estrogen and progesterone receptors and anti-gross cystic disease fluid protein 15 (BRST-2) fail to distinguish metastatic breast carcinoma from eccrine neoplasms. Mod Pathol 1995; 8:897-901.

142 Lee CS, Southey MC, Waters K, Kannourakis G, Georgiou T, Armes JE, Chow CW, Venter DJ: EWS/FLI-1 fusion transcript detection and MIC2 immunohistochemical staining in the diagnosis of Ewing's sarcoma. Pediatr Pathol Lab Med 1996;16:379-392. 
143 Hasegawa SL, Davison JM, Rutten A, Fletcher JA, Fletcher CD: Primary cutaneous Ewing's sarcoma: immunophenotypic and molecular cytogenetic evaluation of five cases. Am J Surg Pathol 1998;22:310-318.

144 Ramani P, Rampling D, Link M: Immunocytochemical study of $12 \mathrm{E} 7$ in small round-cell tumours of childhood: an assessment of its sensitivity and specificity. Histopathology 1993;23:557-561.

145 Fellinger EJ, Garin-Chesa P, Triche TJ, Huvos AG, Rettig WJ: Immunohistochemical analysis of Ewing's sarcoma cell surface antigen p30/32MIC2. Am J Pathol 1991;139:317-325.

146 Machado I, Llombart B, Calabuig-Farinas S, Llombart-Bosch A: Superficial Ewing's sarcoma family of tumors: a clinicopathological study with differential diagnoses. J Cutan Pathol 2011;38:636-643.

147 Llombart-Bosch A, Machado I, Navarro S, Bertoni F, Bacchini P, Alberghini M, Karzeladze A, Savelov N, Petrov S, Alvarado-Cabrero I, Mihaila D, Terrier P, Lopez-Guerrero JA, Picci P: Histological heterogeneity of Ewing's sarcoma/PNET: an immunohistochemical analysis of 415 genetically confirmed cases with clinical support. Virchows Arch 2009;455:397-411.

148 Mhawech-Fauceglia P, Herrmann F, Penetrante R, Beck A, Sait S, Block AM, Odunsi K, Fisher J, Balos L, Cheney RT: Diagnostic utility of FLI-1 monoclonal antibody and dual-colour, break-apart probe fluorescence in situ (FISH) analysis in Ewing's sarcoma/primitive neuroectodermal tumour (EWS/PNET). A comparative study with CD99 and FLI-1 polyclonal antibodies. Histopathology 2006;49:569-575.

149 Folpe AL, Goldblum JR, Rubin BP, Shehata BM, Liu W, Dei Tos AP, Weiss SW: Morphologic and immunophenotypic diversity in Ewing family tumors: a study of 66 genetically confirmed cases. Am J Surg Pathol 2005;29: 1025-1033.

150 Folpe AL, Hill CE, Parham DM, O'Shea PA, Weiss SW: Immunohistochemical detection of FLI-1 protein expression: a study of 132 round cell tumors with emphasis on CD99-positive mimics of Ewing's sarcoma/ primitive neuroectodermal tumor. Am J Surg Pathol 2000;24:1657-1662.

151 Rekhi B, Ahmed S, Basak R, Qureshi SS, Desai SS, Ramadwar M, Desai SB, Kurkure P, Jambhekar NA: Desmoplastic small round cell tumor - clinicopathological spectrum, including unusual features and immunohistochemical analysis of 45 tumors diagnosed at a tertiary cancer referral centre, with molecular results $t(11 ; 22)$ (p13; q12) (EWS-WT1) in select cases. Pathol Oncol Res 2012;18:917-927.

152 Saab R, Khoury JD, Krasin M, Davidoff AM, Navid F: Desmoplastic small round cell tumor in childhood: the St. Jude Children's Research Hospital experience. Pediatr Blood Cancer 2007;49:274-279.

153 Lae ME, Roche PC, Jin L, Lloyd RV, Nascimento AG: Desmoplastic small round cell tumor: a clinicopathologic, immunohistochemical, and molecular study of 32 tumors. Am J Surg Pathol 2002;26:823-835.

154 Drier JK, Swanson PE, Cherwitz DL, Wick MR: S100 protein immunoreactivity in poorly differentiated carcinomas. Immunohistochemical comparison with malignant melanoma. Arch Pathol Lab Med 1987;111:447452.

155 Rossi S, Orvieto E, Furlanetto A, Laurino L, Ninfo V, Dei Tos AP: Utility of the immunohistochemical detection of FLI-1 expression in round cell and vascular neoplasm using a monoclonal antibody. Mod Pathol 2004;17: 547-552.

156 Cantile M, Marra L, Franco R, Ascierto P, Liguori G, De Chiara A, Botti G: Molecular detection and targeting of EWSR1 fusion transcripts in soft tissue tumors. Med Oncol 2013;30:412.

157 Yoshida A, Sekine S, Tsuta K, Fukayama M, Furuta K, Tsuda H: NKX2.2 is a useful immunohistochemical marker for Ewing sarcoma. Am J Surg Pathol 2012;36:993-999.

158 Rekhi B, Gorad BD, Chinoy RF: Proximal-type epithelioid sarcoma - a rare, aggressive subtype of epithelioid sarcoma presenting as a recurrent perineal mass in a middle-aged male. World J Surg Oncol 2007;5:28.

159 Ordonez NG: Desmoplastic small round cell tumor. I. A histopathologic study of 39 cases with emphasis on unusual histological patterns. Am J Surg Pathol 1998;22:1303-1313.

160 Ozdemirli M, Fanburg-Smith JC, Hartmann DP, Azumi N, Miettinen M: Differentiating lymphoblastic lymphoma and Ewing's sarcoma: lymphocyte markers and gene rearrangement. Mod Pathol 2001;14:1175-1182.

161 Kim YC, Lee MG, Choe SW, Lee MC, Chung HG, Cho SH: Acral lentiginous melanoma: an immunohistochemical study of 20 cases. Int J Dermatol 2003;42:123-129.

162 Ben-Izhak O, Stark P, Levy R, Bergman R, Lichtig C: Epithelial markers in malignant melanoma. A study of primary lesions and their metastases. Am J Dermatopathol 1994;16:241-246.

163 Lewis JS, Ritter JH, El-Mofty S: Alternative epithelial markers in sarcomatoid carcinomas of the head and neck, lung, and bladder-p63, MOC-31, and TTF-1. Mod Pathol 2005;18:1471-1481.

164 Wang NP, Marx J, McNutt MA, Rutledge JC, Gown AM: Expression of myogenic regulatory proteins (myogenin and MyoD1) in small blue round cell tumors of childhood. Am J Pathol 1995;147:1799-1810.

165 Cui S, Hano H, Harada T, Takai S, Masui F, Ushigome S: Evaluation of new monoclonal anti-MyoD1 and antimyogenin antibodies for the diagnosis of rhabdomyosarcoma. Pathol Int 1999;49:62-68.

166 Cessna MH, Zhou H, Perkins SL, Tripp SR, Layfield L, Daines C, Coffin CM: Are myogenin and myoD1 expression specific for rhabdomyosarcoma? A study of 150 cases, with emphasis on spindle cell mimics. Am J Surg Pathol 2001;25:1150-1157.

167 Hoot AC, Russo P, Judkins AR, Perlman EJ, Biegel JA: Immunohistochemical analysis of hSNF5/INI1 distinguishes renal and extra-renal malignant rhabdoid tumors from other pediatric soft tissue tumors. Am J Surg Pathol 2004;28:1485-1491.

168 Llombart B, Monteagudo C, Lopez-Guerrero JA, Carda C, Jorda E, Sanmartin O, Almenar S, Molina I, Martin JM, Llombart-Bosch A: Clinicopathological and immunohistochemical analysis of 20 cases of Merkel cell carcinoma in search of prognostic markers. Histopathology 2005;46:622-634. 
169 Lin X, Saad RS, Luckasevic TM, Silverman JF, Liu Y: Diagnostic value of CDX-2 and TTF-1 expressions in separating metastatic neuroendocrine neoplasms of unknown origin. Appl Immunohistochem Mol Morphol 2007; 15:407-414.

170 Beer TW, Shepherd P, Theaker JM: Ber EP4 and epithelial membrane antigen aid distinction of basal cell, squamous cell and basosquamous carcinomas of the skin. Histopathology 2000;37:218-223.

171 Sinard JH: Immunohistochemical distinction of ocular sebaceous carcinoma from basal cell and squamous cell carcinoma. Arch Ophthalmol 1999;117:776-783.

172 Mori O, Hachisuka H, Sasai Y: Immunohistochemical demonstration of epithelial membrane antigen (EMA), carcinoembryonic antigen (CEA), and keratin on mammary and extramammary Paget's disease. Acta Histochem 1989;85:93-100.

173 Zhou JH, Kim KB, Myers JN, Fox PS, Ning J, Bassett RL, Hasanein H, Prieto VG: Immunohistochemical expression of hormone receptors in melanoma of pregnant women, nonpregnant women, and men. Am J Dermatopathol 2014;36:74-79.

174 Clarke LE, Conway AB, Warner NM, Barnwell PN, Sceppa J, Helm KF: Expression of CK7, Cam 5.2 and Ber-Ep4 in cutaneous squamous cell carcinoma. J Cutan Pathol 2013;40:646-650.

175 Layfield L, Ulich T, Liao S, Barr R, Cheng L, Lewin KL: Neuroendocrine carcinoma of the skin: an immunohistochemical study of tumor markers and neuroendocrine products. J Cutan Pathol 1986;13:268-273.

176 Poniecka AW, Alexis JB: An immunohistochemical study of basal cell carcinoma and trichoepithelioma. Am J Dermatopathol 1999;21:332-336.

177 Ahrens WA, Folpe AL: CD1a immunopositivity in perivascular epithelioid cell neoplasms: true expression or technical artifact? A streptavidin-biotin and polymer-based detection system immunohistochemical study of perivascular epithelioid cell neoplasms and their morphologic mimics. Hum Pathol 2011;42:369-374.

178 Galan A, Ko CJ: Langerhans cells in squamous cell carcinoma vs. pseudoepitheliomatous hyperplasia of the skin. J Cutan Pathol 2007;34:950-952.

179 Ko CJ, Kim J, Phan J, Binder SW: Bcl-2-positive epidermal dendritic cells in inverted follicular keratoses but not squamous cell carcinomas or seborrheic keratosis. J Cutan Pathol 2006;33:498-501.

180 Xu X, Chu AY, Pasha TL, Elder DE, Zhang PJ: Immunoprofile of MITF, tyrosinase, melan-A, and MAGE-1 in HMB45-negative melanomas. Am J Surg Pathol 2002;26:82-87.

181 Ohnishi T, Watanabe S: The use of cytokeratins 7 and 20 in the diagnosis of primary and secondary extramammary Paget's disease. Br J Dermatol 2000;142:243-247.

182 Schirren CG, Rutten A, Kaudewitz P, Diaz C, McClain S, Burgdorf WH: Trichoblastoma and basal cell carcinoma are neoplasms with follicular differentiation sharing the same profile of cytokeratin intermediate filaments. Am J Dermatopathol 1997;19:341-350.

183 Mai KT, Alhalouly T, Landry D, Stinson WA, Perkins DG, Yazdi HM: Pagetoid variant of actinic keratosis with or without squamous cell carcinoma of sun-exposed skin: a lesion simulating extramammary Paget's disease. Histopathology 2002;41:331-336.

184 Johansson L, Tennvall J, Akerman M: Immunohistochemical examination of 25 cases of Merkel cell carcinoma: a comparison with small cell carcinoma of the lung and oesophagus, and a review of the literature. APMIS 1990;98:741-752.

185 Stetsenko GY, Malekirad J, Paulson KG, Iyer JG, Thibodeau RM, Nagase K, Schmidt M, Storer BE, Argenyi ZB, Nghiem P: p63 expression in Merkel cell carcinoma predicts poorer survival yet may have limited clinical utility. Am J Clin Pathol 2013;140:838-844.

186 Qureshi HS, Ormsby AH, Lee MW, Zarbo RJ, Ma CK: The diagnostic utility of p63, CK5/6, CK 7, and CK 20 in distinguishing primary cutaneous adnexal neoplasms from metastatic carcinomas. J Cutan Pathol 2004;31:145-152.

187 Plaza JA, Ortega PF, Stockman DL, Suster S: Value of p63 and podoplanin (D2-40) immunoreactivity in the distinction between primary cutaneous tumors and adenocarcinomas metastatic to the skin: a clinicopathologic and immunohistochemical study of 79 cases. J Cutan Pathol 2010;37:403-410.

188 Orchard G: Evaluation of melanocytic neoplasms: application of a pan-melanoma antibody cocktail. Br J Biomed Sci 2002;59:196-202.

189 Rosen L, Amazon K, Frank B: Bowen's disease, Paget's disease, and malignant melanoma in situ. South Med J 1986;79:410-413.

190 Ordonez NG, Awalt H, Mackay B: Mammary and extramammary Paget's disease. An immunocytochemical and ultrastructural study. Cancer 1987;59:1173-1183.

191 Glasgow BJ, Wen DR, Al-Jitawi S, Cochran AJ: Antibody to S-100 protein aids the separation of pagetoid melanoma from mammary and extramammary Paget's disease. J Cutan Pathol 1987;14:223-226.

192 Hultgren TL, DiMaio DJ: Immunohistochemical staining of CD10 in atypical fibroxanthomas. J Cutan Pathol 2007;34:415-419.

193 Anstey A, Cerio R, Ramnarain N, Orchard G, Smith N, Jones EW: Desmoplastic malignant melanoma. An immunocytochemical study of 25 cases. Am J Dermatopathol 1994;16:14-22.

194 Beer TW, Drury P, Heenan PJ: Atypical fibroxanthoma: a histological and immunohistochemical review of 171 cases. Am J Dermatopathol 2010;32:533-540.

195 Thum C, Husain EA, Mulholland K, Hornick JL, Brenn T: Atypical fibroxanthoma with pseudoangiomatous features: a histological and immunohistochemical mimic of cutaneous angiosarcoma. Ann Diagn Pathol 2013; 17:502-507. 
196 Nickoloff BJ, Griffiths CE: The spindle-shaped cells in cutaneous Kaposi's sarcoma. Histologic simulators include factor XIIIa dermal dendrocytes. Am J Pathol 1989;135:793-800.

197 Longacre TA, Egbert BM, Rouse RV: Desmoplastic and spindle-cell malignant melanoma. An immunohistochemical study. Am J Surg Pathol 1996;20:1489-1500.

198 Iyer PV, Leong AS: Poorly differentiated squamous cell carcinomas of the skin can express vimentin. J Cutan Pathol 1992;19:34-39.

199 Morgan MB, Purohit C, Anglin TR: Immunohistochemical distinction of cutaneous spindle cell carcinoma. Am J Dermatopathol 2008;30:228-232.

200 Gleason BC, Calder KB, Cibull TL, Thomas AB, Billings SD, Morgan MB, Hiatt KM, Smoller BR: Utility of p63 in the differential diagnosis of atypical fibroxanthoma and spindle cell squamous cell carcinoma. J Cutan Pathol 2009;36:543-547.

201 Buonaccorsi JN, Plaza JA: Role of CD10, wide-spectrum keratin, p63, and podoplanin in the distinction of epithelioid and spindle cell tumors of the skin: an immunohistochemical study of 81 cases. Am J Dermatopathol 2012;34:404-411.

202 Dotto JE, Glusac EJ: p63 is a useful marker for cutaneous spindle cell squamous cell carcinoma. J Cutan Pathol 2006;33:413-417.

203 Clarke LE, Frauenhoffer E, Fox E, Neves R, Bruggeman RD, Helm KF: CD10-positive myxofibrosarcomas: a pitfall in the differential diagnosis of atypical fibroxanthoma. J Cutan Pathol 2010;37:737-743.

204 Yeh I, McCalmont TH: Distinguishing neurofibroma from desmoplastic melanoma: the value of the CD34 fingerprint. J Cutan Pathol 2011;38:625-630.

205 Hoang MP, Selim MA, Bentley RC, Burchette JL, Shea CR: CD34 expression in desmoplastic melanoma. J Cutan Pathol 2001;28:508-512.

206 Husain S, Silvers DN: Fingerprint CD34 immunopositivity to distinguish neurofibroma from an early/paucicellular desmoplastic melanoma can be misleading. J Cutan Pathol 2013;40:985-987.

207 Rosado FG, Itani DM, Coffin CM, Cates JM: Utility of immunohistochemical staining with FLI1, D2-40, CD31, and CD34 in the diagnosis of acquired immunodeficiency syndrome-related and non-acquired immunodeficiency syndrome-related Kaposi sarcoma. Arch Pathol Lab Med 2012;136:301-304.

208 Miettinen M, Wang ZF, Paetau A, Tan SH, Dobi A, Srivastava S, Sesterhenn I: ERG transcription factor as an immunohistochemical marker for vascular endothelial tumors and prostatic carcinoma. Am J Surg Pathol 2011;35:432-441.

209 Minner S, Luebke AM, Kluth M, Bokemeyer C, Janicke F, Izbicki J, Schlomm T, Sauter G, Wilczak W: High level of Ets-related gene expression has high specificity for prostate cancer: a tissue microarray study of 11483 cancers. Histopathology 2012;61:445-453.

210 Weissinger SE, Keil P, Silvers DN, Klaus BM, Moller P, Horst BA, Lennerz JK: A diagnostic algorithm to distinguish desmoplastic from spindle cell melanoma. Mod Pathol 2014;27:524-534.

-211 Spandidos DA, Kaloterakis A, Yiagnisis M, Varatsos A, Field JK: Ras, C-myc and C-erbB-2 oncoprotein expression in non-AIDS Mediterranean Kaposi's sarcoma. Anticancer Res 1990;10:1619-1625.

212 Feller JK, Mahalingam M: c-myc and cutaneous vascular neoplasms. Am J Dermatopathol 2013;35:364-369.

213 Schmid H, Zietz C: Human herpesvirus 8 and angiosarcoma: analysis of 40 cases and review of the literature. Pathology 2005;37:284-287.

214 Cheuk W, Wong KO, Wong CS, Dinkel JE, Ben-Dor D, Chan JK: Immunostaining for human herpesvirus 8 latent nuclear antigen-1 helps distinguish Kaposi sarcoma from its mimickers. Am J Clin Pathol 2004;121:335-342.

215 Wick MR, Cooper PH, Swanson PE, Kaye VN, Sun TT: Microcystic adnexal carcinoma. An immunohistochemical comparison with other cutaneous appendage tumors. Arch Dermatol 1990;126:189-194.

216 Hoang MP, Dresser KA, Kapur P, High WA, Mahalingam M: Microcystic adnexal carcinoma: an immunohistochemical reappraisal. Mod Pathol 2008;21:178-185.

217 Krahl D, Sellheyer K: Monoclonal antibody Ber-EP4 reliably discriminates between microcystic adnexal carcinoma and basal cell carcinoma. J Cutan Pathol 2007;34:782-787.

218 Pulitzer M, Desman G, Busam KJ: CK7 expression in primary cutaneous squamous cell carcinoma. J Cutan Pathol 2010;37:966-972.

219 Plumb SJ, Argenyi ZB, Stone MS, De Young BR: Cytokeratin 5/6 immunostaining in cutaneous adnexal neoplasms and metastatic adenocarcinoma. Am J Dermatopathol 2004;26:447-451.

220 Sigel JE, Skacel M, Bergfeld WF, House NS, Rabkin MS, Goldblum JR: The utility of cytokeratin 5/6 in the recognition of cutaneous spindle cell squamous cell carcinoma. J Cutan Pathol 2001;28:520-524.

-21 Abbas O, Richards JE, Yaar R, Mahalingam M: Stem cell markers (cytokeratin 15, cytokeratin 19 and p63) in in situ and invasive cutaneous epithelial lesions. Mod Pathol 2011;24:90-97.

222 Tse JY, Nguyen AT, Le LP, Hoang MP: Microcystic adnexal carcinoma versus desmoplastic trichoepithelioma: a comparative study. Am J Dermatopathol 2013;35:50-55.

223 Anderson-Dockter H, Clark T, Iwamoto S, Lu M, Fiore D, Falanga JK, Falanga V: Diagnostic utility of cytokeratin 17 immunostaining in morpheaform basal cell carcinoma and for facilitating the detection of tumor cells at the surgical margins. Dermatol Surg 2012;38:1357-1366.

224 Abbas 0, Bhawan J: Expression of stem cell markers nestin and cytokeratin 15 and 19 in cutaneous malignancies. J Eur Acad Dermatol Venereol 2011;25:311-316.

225 Collini P, Sampietro G, Bertulli R, Casali PG, Luksch R, Mezzelani A, Sozzi G, Pilotti S: Cytokeratin immunoreactivity in 41 cases of ES/PNET confirmed by molecular diagnostic studies. Am J Surg Pathol 2001;25:273-274. 
226 Kolhe R, Reid MD, Lee JR, Cohen C, Ramalingam P: Immunohistochemical expression of PAX5 and TdT by Merkel cell carcinoma and pulmonary small cell carcinoma: a potential diagnostic pitfall but useful discriminatory marker. Int J Clin Exp Pathol 2013;6:142-147.

227 Buresh CJ, Oliai BR, Miller RT: Reactivity with TdT in Merkel cell carcinoma: a potential diagnostic pitfall. Am J Clin Pathol 2008;129:894-898.

228 Drlicek M, Bodenteich A, Urbanits S, Grisold W: Immunohistochemical panel of antibodies in the diagnosis of brain metastases of the unknown primary. Pathol Res Pract 2004;200:727-734.

229 Rajagopalan A, Browning D, Salama S: CD99 expression in Merkel cell carcinoma: a case series with an unusual paranuclear dot-like staining pattern. J Cutan Pathol 2013;40:19-24.

230 Pilkington GR, Pallesen G: Phenotypic characterization of non-haemopoietic small cell tumours of childhood with monoclonal antibodies to leucocytes, epithelial cells and cytoskeletal proteins. Histopathology 1989;14: 347-357.

231 Sheppard MN, Corrin B, Bennett MH, Marangos PJ, Bloom SR, Polak JM: Immunocytochemical localization of neuron specific enolase in small cell carcinomas and carcinoid tumours of the lung. Histopathology 1984;8: 171-181.

232 Bergh J, Esscher T, Steinholtz L, Nilsson K, Pahlman S: Immunocytochemical demonstration of neuron-specific enolase (NSE) in human lung cancers. Am J Clin Pathol 1985;84:1-7.

233 Reeve JG, Stewart J, Watson JV, Wulfrank D, Twentyman PR, Bleehen NM: Neuron specific enolase expression in carcinoma of the lung. Br J Cancer 1986;53:519-528.

234 Sullivan LM, Atkins KA, LeGallo RD: PAX immunoreactivity identifies alveolar rhabdomyosarcoma. Am J Surg Pathol 2009;33:775-780.

235 Mhawech-Fauceglia P, Saxena R, Zhang S, Terracciano L, Sauter G, Chadhuri A, Herrmann FR, Penetrante R: Pax-5 immunoexpression in various types of benign and malignant tumours: a high-throughput tissue microarray analysis. J Clin Pathol 2007;60:709-714.

236 Dong HY, Liu W, Cohen P, Mahle CE, Zhang W: B-cell specific activation protein encoded by the PAX-5 gene is commonly expressed in Merkel cell carcinoma and small cell carcinomas. Am J Surg Pathol 2005;29:687-692.

237 Desouki MM, Post GR, Cherry D, Lazarchick J: PAX-5: a valuable immunohistochemical marker in the differential diagnosis of lymphoid neoplasms. Clin Med Res 2010;8:84-88.

238 Wilkerson AE, Glasgow MA, Hiatt KM: Immunoreactivity of CD99 in invasive malignant melanoma. J Cutan Pathol 2006;33:663-666.

239 Torlakovic EE, Slipicevic A, Florenes VA, Chibbar R, DeCoteau JF, Bilalovic N: Fli-1 expression in malignant melanoma. Histol Histopathol 2008;23:1309-1314. 